\title{
Philosciids with pleopodal lungs from Brazil, with description of a new species (Crustacea, Isopoda)
}

\author{
Paula Beatriz Araujo ${ }^{1}$ \& Andreas Leistikow ${ }^{2}$ \\ 'Departamento de Zoologia, IB, Universidade Federal do Rio Grande do Sul, Av. Paulo Gama, pr. 12105, \\ CEP 90040-060, Porto Alegre, RS, Brazil, e-mail: pbaraujo@portoweb.com.br; ${ }^{2}$ Universität Bielefeld, Ab- \\ teilung für Zoomorphologie und Systematik, Morgenbreede 45, D-33615, Bielefeld, e-mail: leiste@ \\ biologie.uni-bielefeld.de
}

Keywords: Crustacea, Peracarida, Isopoda, phillosciids, pleopodal lungs, bỉogeography, Brazil

\begin{abstract}
Several species of "philosciid" Oniscidea are known from Brazil, most of them were found in the southern and eastern parts of this country. The genera Atlantoscia Ferrara \& Taiti, 1981, Benthana Budde-Lund, 1908 and Balloniscus Budde-Lund, 1908, the latter considered to represent a separate family Balloniscidae Vandel, 1963, are considered the only neotropical philosciids bearing respiratory areas on their pleopods. Therefore, representatives of these genera are re-examined to shed new light on the question whether these species can be considered to be a monophylum with the autapomorphy "respiratory areas present" ${ }^{2}$ The phylogeny of the above-mentioned genera is discussed under morphological and biogeographical aspects. Furthermore, a remarkable new species of Atlantoscia Ferrara \& Taiti, 1981, which bears pleopodal lungs in all five pairs of pleopods, is described. In regard to this character, it differs from its sister species Atlantoscia floridana (Van Name, 1940). Additionally, the hitherto unknown male of Benthana convexa Lemos de Castro, 1958 will be described; it is evident that this species is different from its closest relative B. schubarti Lemos de Castro, 1958, which is also found in Brazil.
\end{abstract}

\section{Contents}

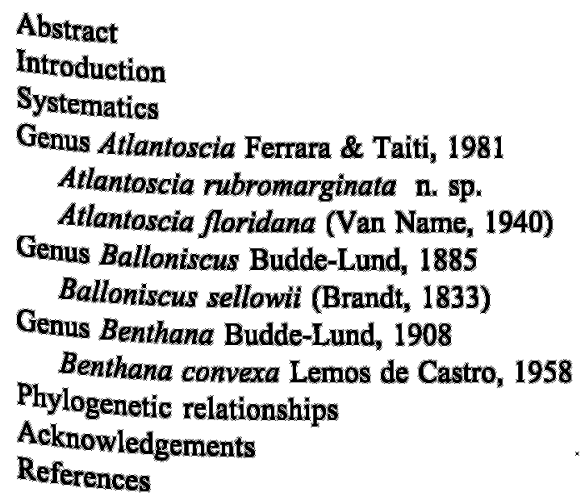

\section{Introduction}

South America is especially rich in "philosciid" Oniscidea, although our knowledge is far from being complete. Several authors contributed to our knowledge in the last century, but most of the older descriptions do not support phylogenetic evidence. Budde-Lund (1908) was the first to discriminate subgenera among the species described as belonging to Philoscia Latreille, 1804. His subgenera are nowadays elevated to generic rank. Lemos de Castro (1958a) contributed to our understanding of the specific and generic limits of Benthana (BuddeLund, 1908), giving additional information to Gruner's (1955) revision of this genus, although the descriptions are rather incomplete. In a later work, he clarified the status of Balloniscus sellowi (Brandt, 1833) with its puzzling synonymy (Lemos de Castro 1958b, 1976). Balloniscus Budde-Lund, 1885. was separated in its own family by Vandel (1963) mainly on the fact that the species of this genus bear pleopodal lungs in all five pairs of pleopods. Since the occurrence of pleopodal lungs in members of the so-called "Philosciidae", particularly in the Afro-tropical genus Aphiloscia Budde-Lund, 1908, is nowadays recognized (Ferrara et al. 1994), the separation of one or two genera in a family is rather unsatisfactory and even useless for reconstruction of phylogeny.

Benthana and Balloniscus both are typical genera for the coastal Atlantic forests of Brazil where they occur together with Atlantoscia floridana (Van Name, 1940). Four species of these genera are described in detail in the following, and their sys- 
tematic position will be discussed with regards to phylogenetic and biogeographical aspects.

The following acronyms are used: MNRJ Museu Nacional, Rio de Janeiro, Brazil; SMNS Staatliches Museum für Naturkunde, Stuttgart, Germany; UFRGS Universidade Federal do Rio Grande do Sul, Porto Alegre, Brazil; ZMA Zoological Museum Amsterdam, The Netherlands.

\section{Systematics}

Genus Atlantoscia Ferrara \& Taiti, 1981

Synonymy - Ocelloscia Schultz \& Johnson, 1984.

A detailed diagnosis of this genus was given when the genus was first established (Ferrara \& Taiti 1981) to comprise a species from Ascension Island, which was thought to be identical with Philoscia floridana Van Name, 1940 by Lemos de Castro (1985). Some additions to the diagnosis should be made: Antennula with conical apex, medial set of aesthetascs paired and graded, antennal flagellum with apical organ shorter than distal article, free sensilla almost as long as cuticular sheath. Medial endite of maxillula without apical tip, medial lobe of maxilla with three rows of cusps, maxillipedal basis with sulcus lateralis, proximal setal tuft of palp consisting of a short and a long seta. Pereiopod 1 carpus with transverse antenna-grooming brush rostrally, ornamental seta apically double fringed serrate, dactylus with long inner claw, dactylar seta terminating with a small knob. ।

Type species. - Atlantoscia alceui Ferrara \& Taiti, 1981 (junior synonym of Philoscia floridana Van Name, 1940), by monotypy

Remarks. - Atlantoscia Ferrara \& Taiti, 1981 belongs to a phyletic line different from most of the neotropical philosciid Oniscidea and characterized by the shape of the antennula, the structure of the apical organ of the antenna, and the short noduli laterales. The structure of the cephalothorax is quite similar to several smaller genera of the Andes (pers. obs.), and all these structures comprise plesiomorphies. The apomorphic characters of this ge- nus are the shape of the dactylar seta, several sensory spines of carpus and merus with small subapical tip (e.g., Fig. 8, Sc4), reduction of the tip on the medial endite of the maxillula, the lateral lobe of the maxilla apically truncate.

Atlantoscia rubromarginata n. sp. (Figs. 1-5)

Material. - Holotype o $10 \mathrm{~mm}$, Brazil, Sergípe State, Barra

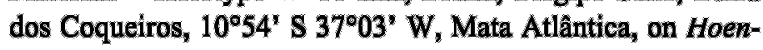
bergia sp., coll. Dr. Erminda da Conceição G. Couto, 29.08.1995, MNRJ 12332; paratypes 2 \% o same data as holotype, MNRJ 12333; paratypes 10,3 우 (partially ovigerous), same data as holotype, collection A. Leistikow; paratypes $10,1 \%, 1$ \% (ovigerous), Brazil, Sergipe State, Crasto, soil, coll. P.B. Araujo and C. Assis, 02.04.1998, SMNS T437.

Additional material: $10,1 \%, 1 \%$ (ovigerous), Brazil, Sergipe State, Crasto, soil, coll. P.B. Araujo and C. Assis, 02.04.1998, UFRGS 2319; 3 \% (ovigerous), same data, ZMA Is, 203915.

Color: Dorsally chestnut with lighter median area and some non-pigmented spots on tergites, coxal plates marginally buff, in vivo reddish, cephalothorax chestnut with many non-pigmented muscle insertion spots on vertex, pleon as pereion but only two paramedian pale spots on pleonite 1 and 2 , ventrally yellowish.

Cephalothorax: Without linea frontalis, linea supra-antennalis prominent, very small lamina frontalis, vertex somewhat arched, small lateral lobes, compound eyes composed of about 23 ommatidia arranged in four rows (Fig. 1, Ctf).

Pereion: Tegument rather smooth and shiny with only scattered tricorn-like setae, coxal plates I to V caudally rounded, V to VII caudally pointed, bearing sulcus marginalis, few gland pores and noduli laterales; nodulus lateralis of coxal plate IV more dorsally than the others (Fig. 5, Cx4).

Pleon: Set back from pereion, neopleurae of pleon segments 3 to 5 conspicuous, pleotelson with concave lateral margins, bearing tricorn-like setae.

Antennula: Tri-articulate with distal article coniform, almost of half the length of appendage, medially bearing three sets of aesthetascs and apical set (Fig. 1, An1).

Antenna: Rather slender, flagellum tri-articulate, as long as peduncular article 5, proximal article the longest, distal joint bearing short apical organ 


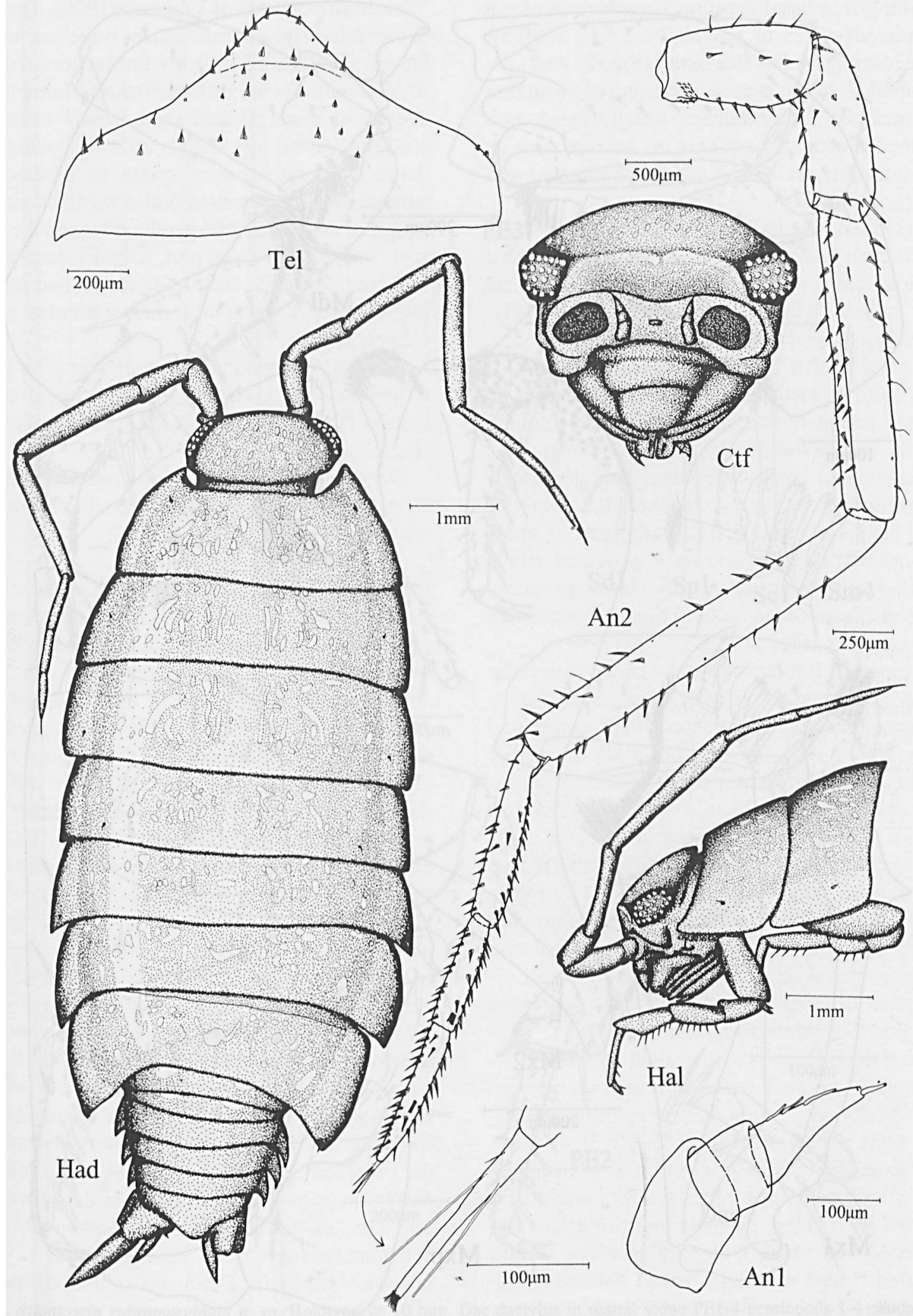

Fig. 1. Atlantoscia rubromarginata n. sp. An1 antennula; An2 antenna; Ctf cephalothorax in frontal view; Had habitus in dorsal view; Hal habitus in lateral view; Tel pleotelson. 


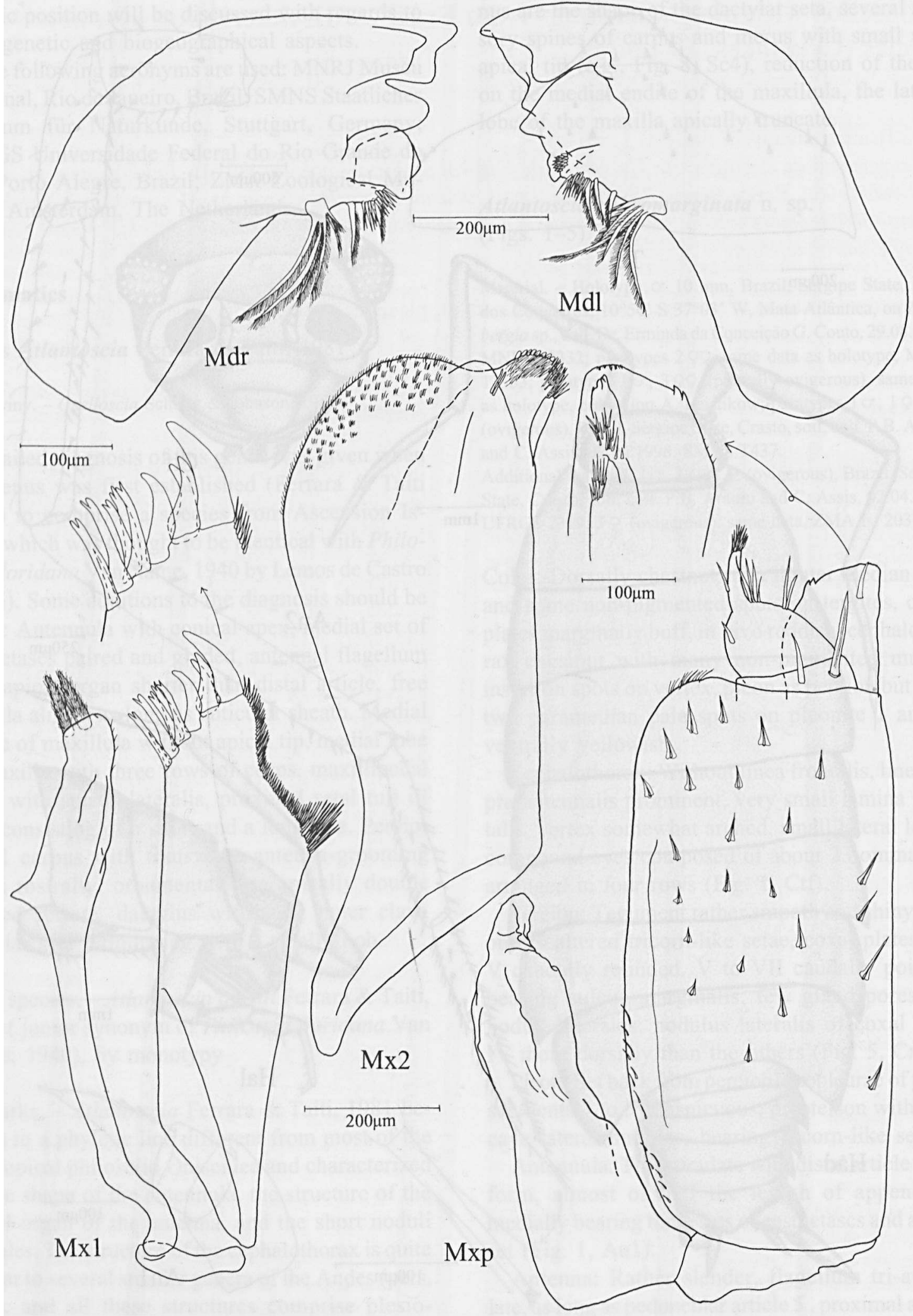

Fig. 2. Atlantoscia rubromarginata $\mathrm{n}$. sp. Holotype $\sigma^{\circ} 10 \mathrm{~mm}$. Mdl/r left and right mandible; Mxp maxillipede with detail of endite in rostral view; Mx1 maxillula with detail of apex of lateral endite; $M \times 2$ maxilla. 


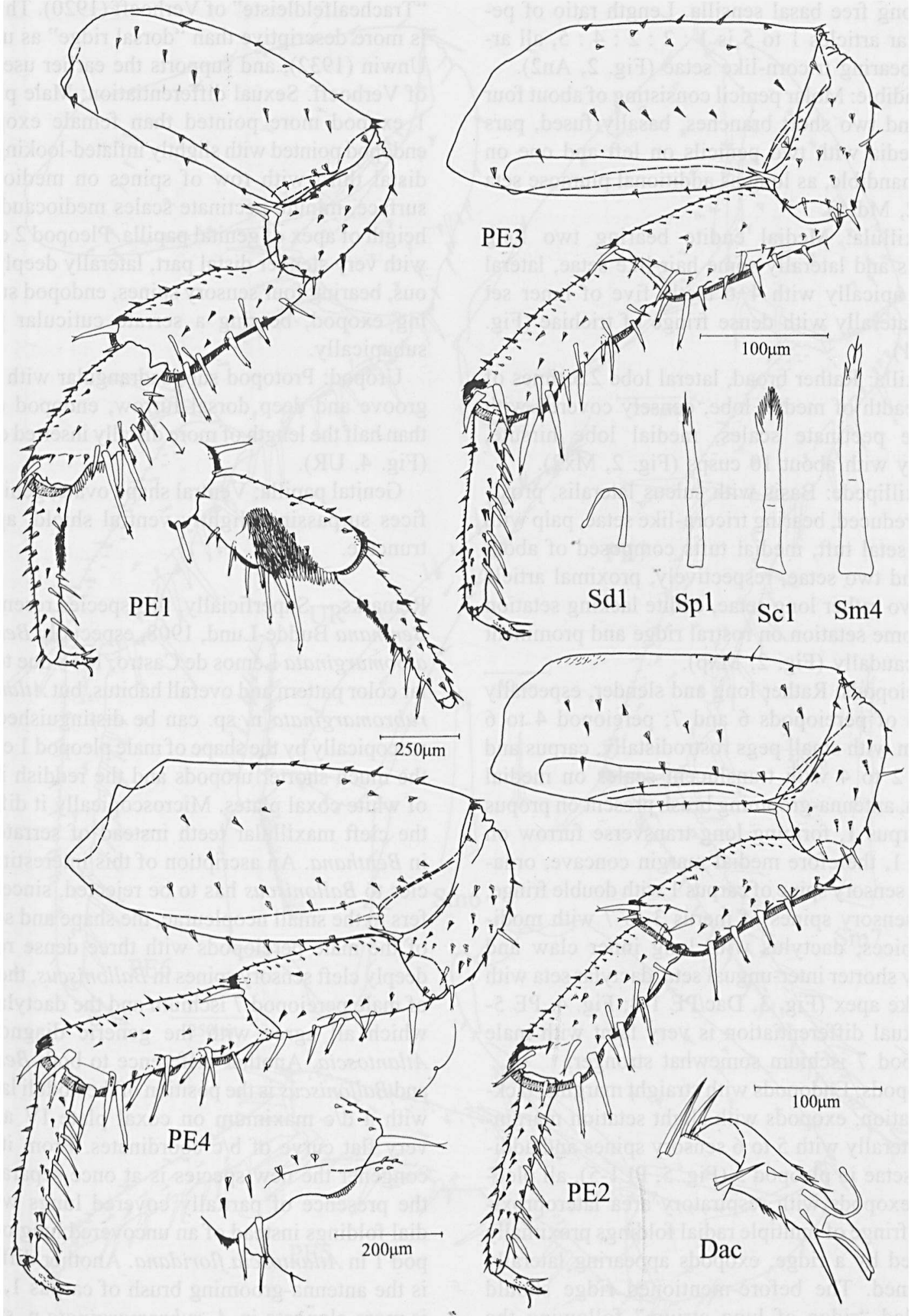

Fig. 3. Atlantoscia rubromarginata n. sp. Holotype ơ $10 \mathrm{~mm}$. Dac dactylus in rostral view; PE1-4 pereiopods $1-4$ caudal view, details in rostral view; $\mathrm{Scl}$ ornamental sensory spine of carpus 1; Sdl dactylar seta of dactylus 1; Sm4 sensory spine of merus 4; Spl sensory spine of propus 1 . 
with long free basal sensilla. Length ratio of peduncular articles 1 to 5 is $1: 2: 2: 4: 5$, all articles bearing tricorn-like setae (Fig. 2, An2).

Mandible: Molar penicil consisting of about four long and two short branches, basally fused, pars intermedia with two penicils on left and one on right mandible, as long as additional plumose seta (Fig. 2, Mdl/r).

Maxillula: Medial endite bearing two long penicils and laterally some hair-like setae, lateral endite apically with $4+6$ teeth, five of inner set cleft, laterally with dense fringe of trichiae (Fig. 2, Mx1).

Maxilla: Rather broad, lateral lobe 2.5 times of the breadth of medial lobe, densely covered with hyaline pectinate scales, medial lobe hirsute, apically with about 10 cusps (Fig. 2, Mx2).

Maxillipede: Basis with sulcus lateralis, proximally reduced, bearing tricorn-like setae, palp with apical setal tuft, medial tufts composed of about four and two setae, respectively, proximal article with two rather long setae, endite lacking setation save some setation on rostral ridge and prominent tooth caudally (Fig. 2, Mxp).

Pereiopods: Rather long and slender, especially propus of pereiopods 6 and 7 ; pereiopod 4 to 6 ischium with small pegs rostrodistally, carpus and merus 2 to 4 with translucent scales on medial margin, antenna-grooming brush present on propus and carpus 1 , forming long transverse furrow on carpus 1 , therefore medial margin concave, ornamental sensory spine of carpus 1 with double fringe, some sensory spines of merus 3 to 7 with modified apices, dactylus with long inner claw and slightly shorter inter-ungual seta, dactylar seta with club-like apex (Fig. 3, Dac/PE 1-4; Fig. 4, PE 57). Sexual differentiation is very faint with male pereiopod 7 ischium somewhat stronger.

Pleopods: Endopods with straight margins, lacking setation, exopods with slight setation marginally, laterally with 5 to 6 sensory spines and additional setae in pleopod 5 (Fig. 5, PL1-5), all pleopodal exopods with respiratory area lateroproximally: fringe of multiple radial foldings proximally bordered by a ridge, exopods appearing laterally broadened. The before-mentioned ridge should be called "ridge of lung atrium" following the terminology used by Hoese (1983) and the term
"Trachealfeldleiste" of Verhoeff (1920). This term is more descriptive than "dorsal ridge" as used by Unwin (1932), and supports the earlier used term of Verhoeff. Sexual differentiation: Male pleopod 1 exopod more pointed than female exopod 1 , endopod pointed with slightly inflated-looking apex, distal third with row of spines on mediocaudal surface, minute pectinate scales mediocaudally at heigth of apex of genital papilla. Pleopod 2 exopod with very slender distal part, laterally deeply sinuous, bearing four sensory spines, endopod surpassing exopod, bearing a serrate cuticular plaque subapically.

Uropod: Protopod subquadrangular with lateral groove and deep dorsal furrow, endopod of less than half the length of more distally inserted exopod (Fig. 4, UR).

Genital papilla: Ventral shape ovate, genital orifices surpassing slightly ventral shield, apically truncate.

Remarks. - Superficially, this species resembles a Benthana Budde-Lund, 1908, especially Benthana albomarginata Lemos de Castro, 1958 due to similar color pattern and overall habitus, but Atlantoscia rubromarginata $\mathrm{n}$. $\mathrm{sp}$. can be distinguished macroscopically by the shape of male pleopod 1 exopod, the much shorter uropods and the reddish instead of white coxal plates. Microscopically it differs in the cleft maxillular teeth instead of serrate teeth in Benthana. An ascription of this interesting species to Balloniscus has to be rejected, since it differs in the small neopleurae, the shape and setation of the male pereiopods with three dense rows of deeply cleft sensory spines in Balloniscus, the shape of male pereiopod 7 ischium and the dactylar seta, which all agree with the generic diagnosis of Atlantoscia. Another difference to both Benthana and Balloniscus is the position of the noduli laterales with a $\mathrm{d} / \mathrm{c}$ maximum on coxal plate IV and the very flat curve of $b / c$ coordinates. From its only congener the new species is at once separated by the presence of partially covered lungs with radial foldings instead of an uncovered lung of pleopod 1 in Atlantoscia floridana. Another difference is the antenna-grooming brush of carpus 1 , which is more elongate in $A$. rubromarginata $\mathrm{n}$. sp. than in A. floridana. 


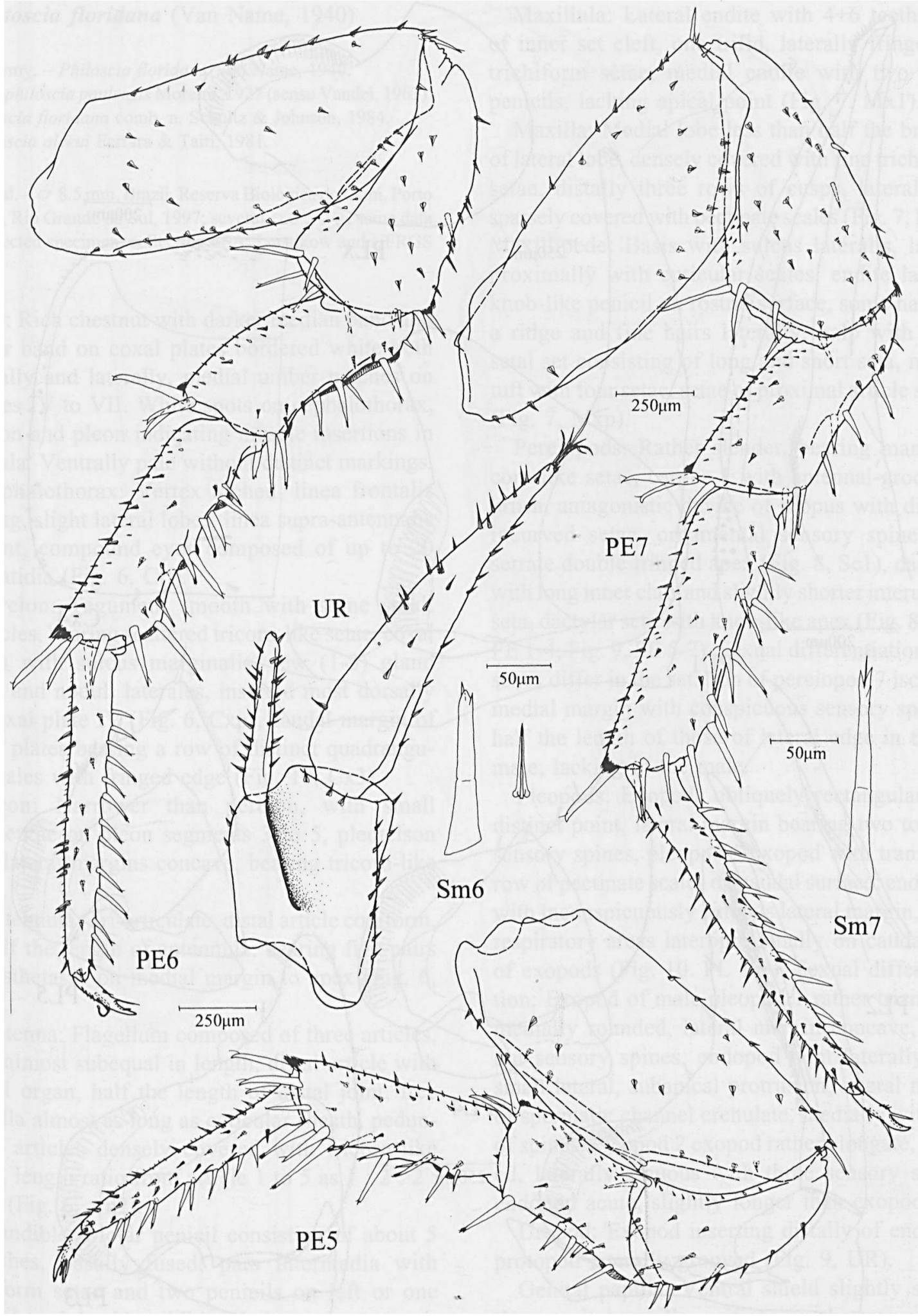

Fig. 4. Atlantoscia rubromarginata n. sp. Holotype or $10 \mathrm{~mm}$. PE5-7 pereiopods 5-7 in caudal view; Sm6 sensory spine and tricorniike seta of merus $6 ; \operatorname{Sm} 7$ sensory spine of merus 7; UR uropod. 


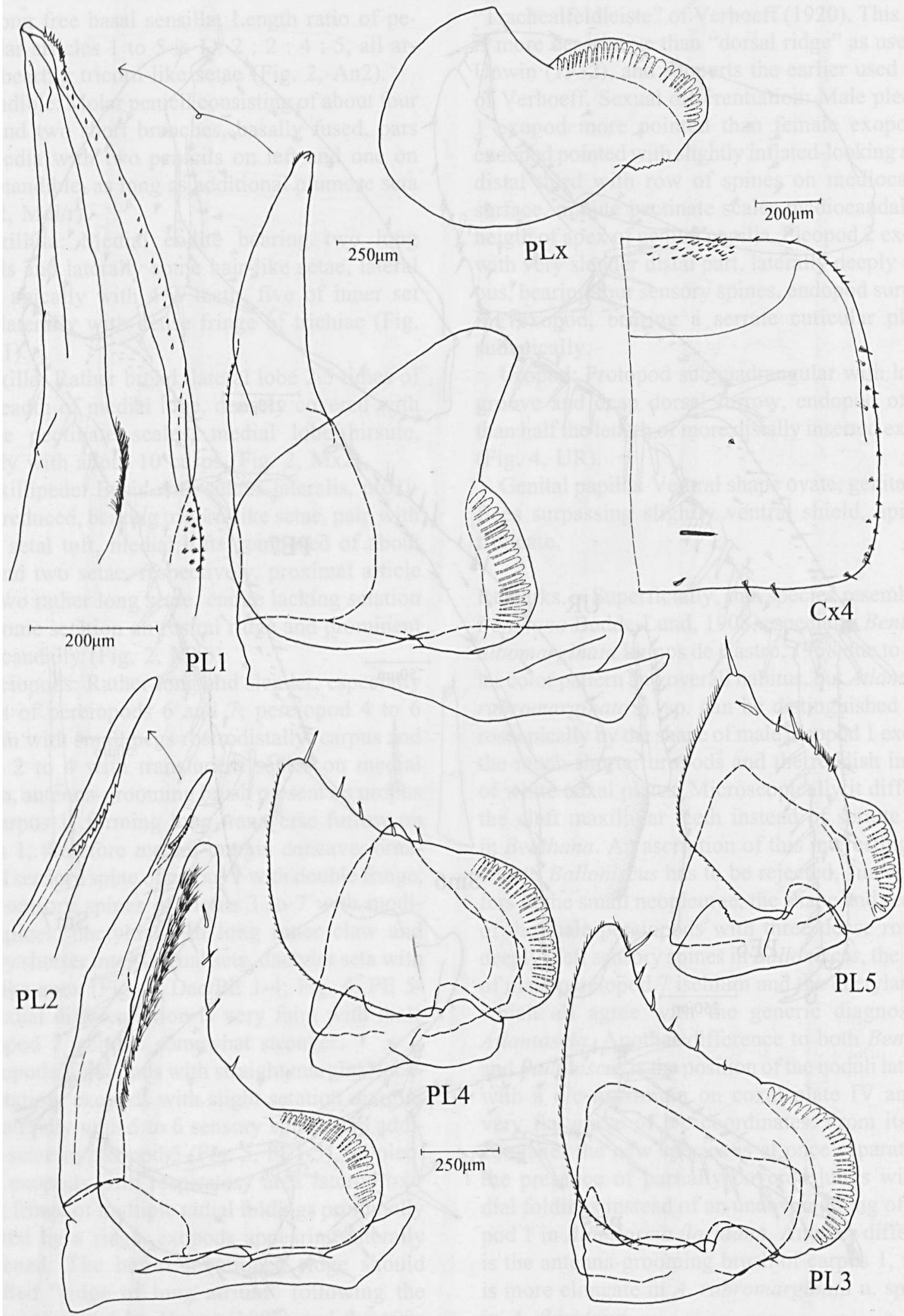

Fig. 5. Atlantoscia rubromarginata $\mathrm{n}$. sp. Holotype o $10 \mathrm{~mm}$. Cx4 coxal plate IV; PL1-5 pleopods $1-5$ with details of endopods 1 (rostrally) and 2 (caudally); Plx pleopod 1 exopod (paratype, $ᄋ 12 \mathrm{~mm}$ ). 
Atlantoscia floridana (Van Name, 1940)

Synonymy, - Philoscia floridana Van Name, 1940.

Chaetophiloscia paulensis Moteira, 1927 (sensu Vandel, 1963).

Ocelloscia floridana comb. n. Schultz \& Johnson, 1984.

Atlantoscia alceui Ferrara \& Taiti, 1981.

Material - 0 $8.5 \mathrm{~mm}$, Brazil, Reserva Biológica do Lami, Porto Alegre, Rio Grande do Sul, 1997; several o'o", ९९, same data as dissected specimen, collection of A. Leistikow and UFRGS 2429.

Color: Rich chestnut with darker median band and umber band on coxal plates bordered white both medially and laterally, medial umber patches on tergites IV to VII. White spots on cephalothorax, pereion and pleon indicating muscle insertions in cuticula. Ventrally pale without distinct markings.

Cephalothorax: Vertex arched, linea frontalis lacking, slight lateral lobes, linea supra-antennalis present, compound eyes composed of up to 20 ommatidia (Fig. 6, Ctf).

Pereion: Tegument smooth with some small tubercles, bearing scattered tricorn-like setae, coxal plates with sulcus marginalis, few (1-3) gland pores and noduli laterales, inserted most dorsally on coxal plate IV (Fig. 6, Cxp), caudal margin of coxal plates bearing a row of distinct quadrangular scales with fringed edge (Fig. 10, Cx3)

Pleon: Narrower than pereion, with "small neopleurae on pleon segments 3 to 5 , pleotelson with lateral margins concave, bearing tricorn-like setae.

Antennula: Tri-articulate, distal article coniform, of half the length of antennula, bearing five pairs of aesthetascs on medial margin to apex (Fig. 6, An1).

Antenna: Flagellum composed of three articles, each almost subequal in length, distal article with apical organ, half the length of distal joint, free sensilla almost as long as cuticular sheath, peduncular articles densely covered with tricorn-like setae, length ratio from article 1 to 5 as $1: 2: 2$ : $3: 4$ (Fig. 6, An2).

Mandible: Molar penicil consisting of about 5 branches, basally fused, pars intermedia with coniform setae and two penicils on left or one penicil on right side, additional plumose seta proximally (Fig. 7, Mdl/r).
Maxillula: Lateral endite with $4+6$ teeth, five of inner set cleft, one trifid, laterally fringed by trichiform setae, medial endite with two weak penicils, lacking apical point (Fig. 7, Mx1).

Maxilla: Medial lobe less than half the breadth of lateral lobe, densely covered with fine trichiform setae, distally three rows of cusps, lateral lobe sparsely covered with pectinate scales (Fig. 7, Mx2). Maxillipede: Basis with sulcus lateralis, lateroproximally with cuticular scales, endite lacking knob-like penicil on rostral surface, some hairs on a ridge and fine hairs laterally, palp with inner setal set consisting of long and short seta, medial tuft with four setae, setae of proximal article strong (Fig. 7, Mxp).

Pereiopods: Rather slender, bearing many tricorn-like setae, carpus 1 with antennal-grooming brush, antagonistic device of propus with distally incurved setae, ornamental sensory spine with serrate double fringed apex (Fig. 8, Sc1), dactylus with long inner claw and slightly shorter interungual seta, dactylar seta with knob-like apex (Fig. 8, Dac, PE 1-4; Fig. 9, PE 5-7). Sexual differentiation: The sexes differ in the setation of pereiopod 7 ischium: medial margin with conspicuous sensory spine of half the length of those of lateral edge in the female, lacking in the male.

Pleopods: Exopods obliquely rectangular with distinct point, lateral margin bearing two to three sensory spines, pleopod 5 exopod with transverse row of pectinate scales on caudal surface; endopods with inconspicuously sinuous lateral margin, small respiratory areas lateroproximally on caudal side of exopods (Fig. 10. PL 1-5). Sexual differentiation: Exopod of male pleopod 1 rather triangular, medially rounded, lateral margin concave, without sensory spines, endopod bent laterally with small lateral, subapical protrusion, lateral margin of spermatic channel crenulate, medially with row of spines. Pleopod 2 exopod rather elongate, pointed, laterally sinuous with three sensory spines, endopod acute, slightly longer than exopod.

Uropod: Exopod inserting distally of endopod, protopod laterally grooved (Fig. 9, UR).

Genital papilla: Ventral shield slightly shorter than genital papilla, orifices on the transversely truncate apical margin (Fig. 10, Gen). 


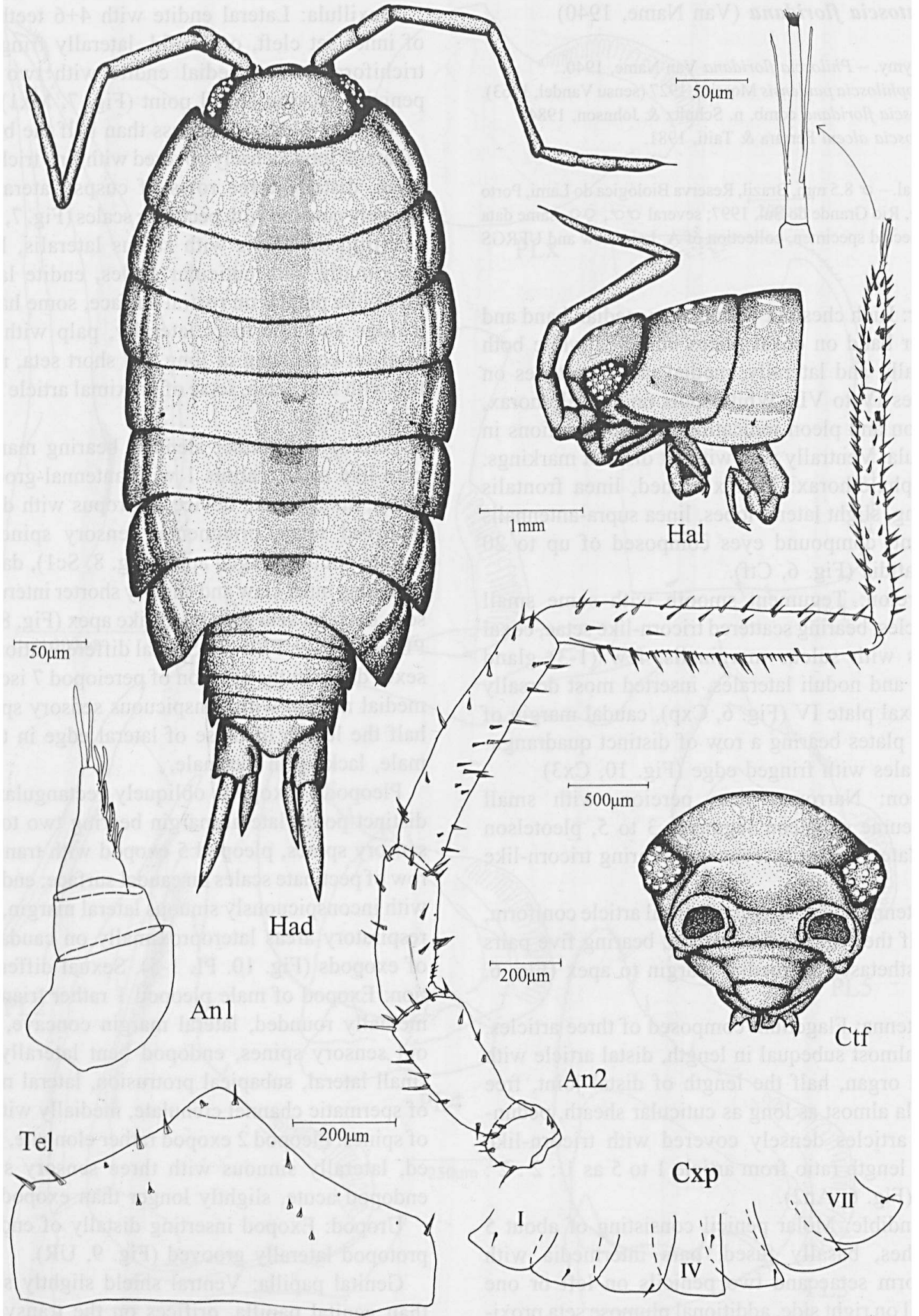

Fig. 6. Atlantoscia floridana (Van Name, 1940) o $8 \mathrm{~mm}$. An1 antennula; An2 antenna; Ctf cephalothorax in frontal view; Cxp position of noduli laterales; Had habitus in dorsal view; Hal habitus in lateral view; Tel pleotelson. 


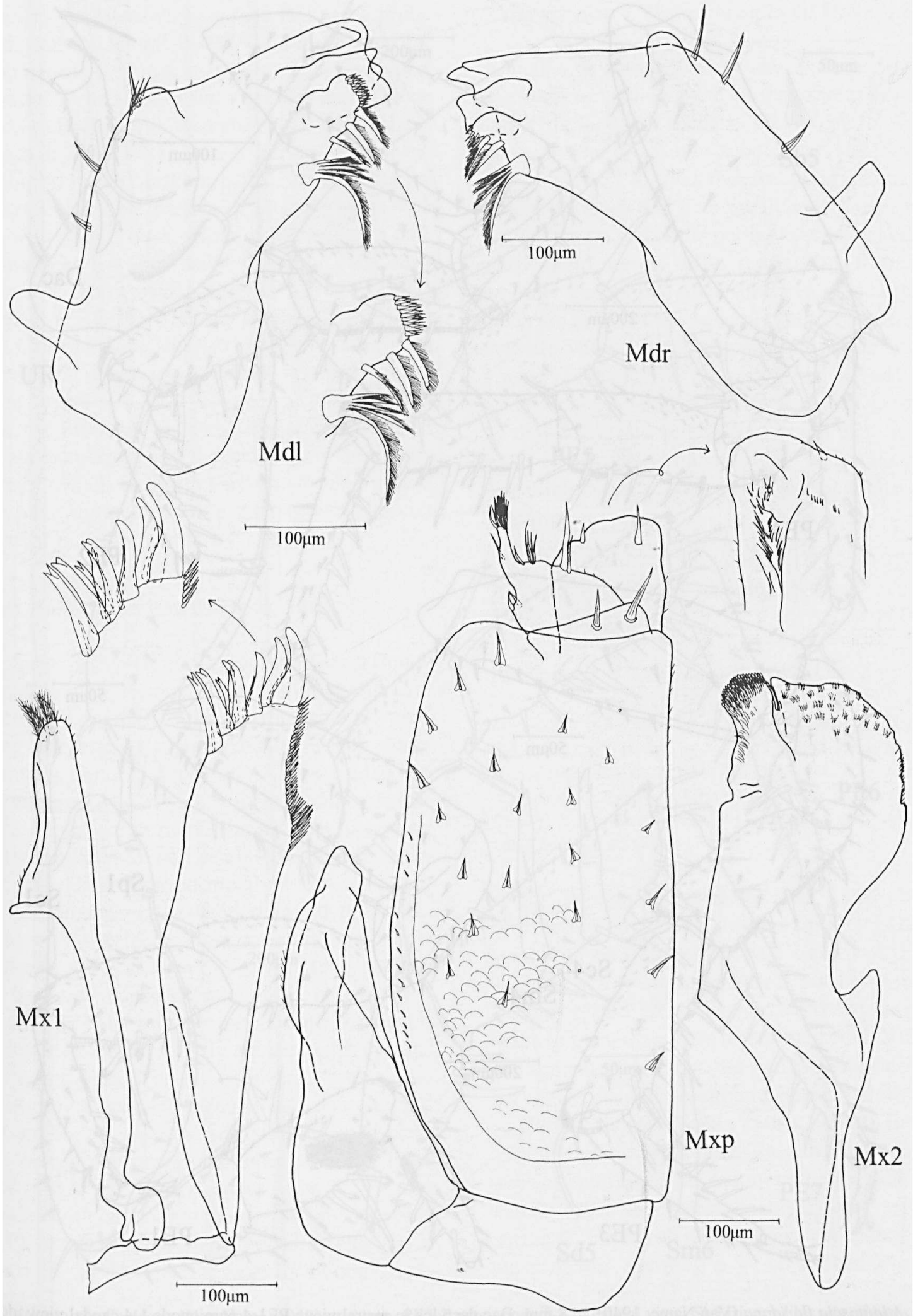

Fig. 7. Atlantoscia floridana (Van Name, 1940) o $8 \mathrm{~mm}$. Mdl/r left and right mandible with detail of pars intermedia of left one; ivixp maxillipede with detail of endite in rostral view; Mx1 maxillula with detail of apex of lateral endite; $\mathrm{Mx} 2$ maxilla. 


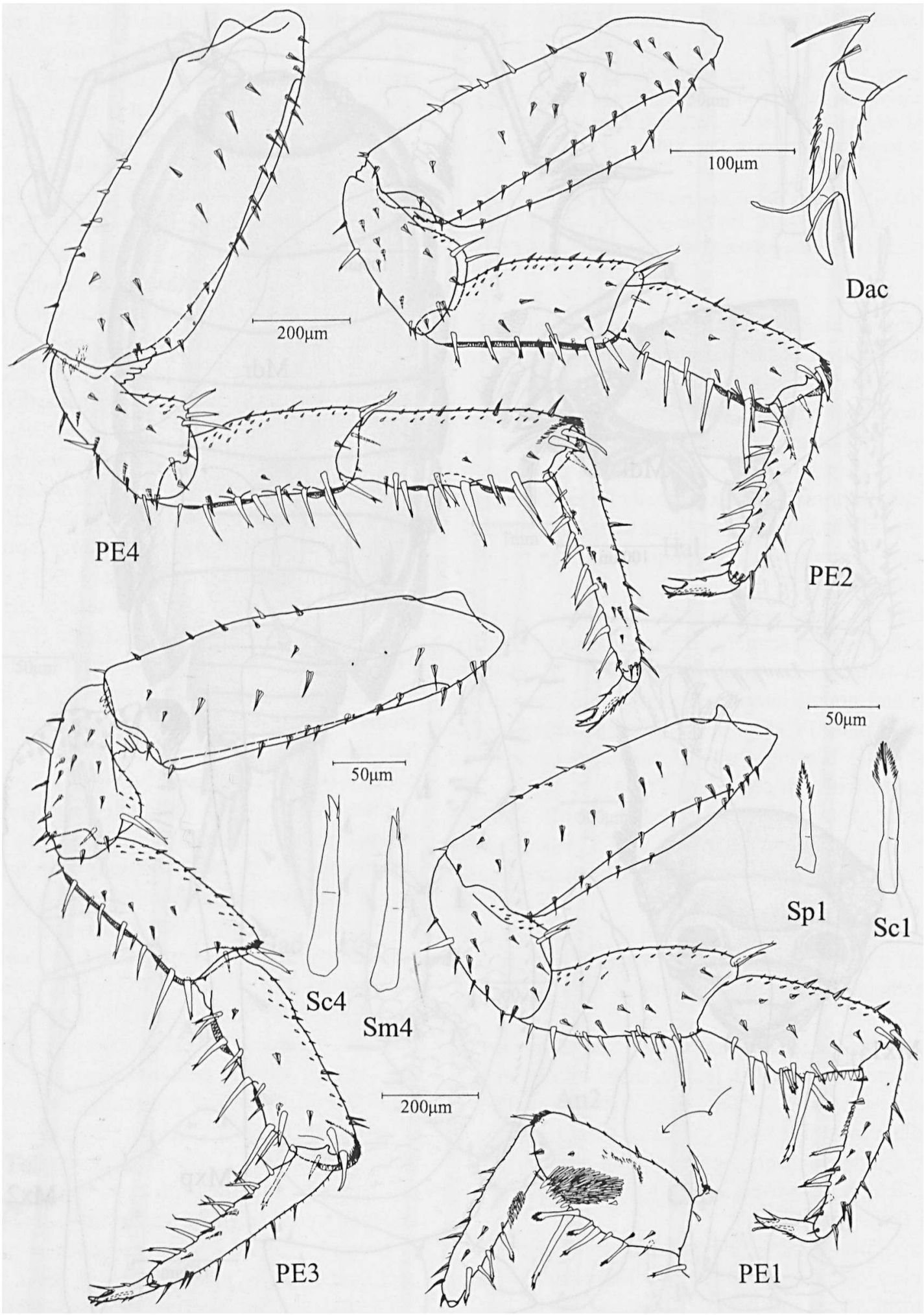

Fig. 8. Atlantoscia floridana (Van Name, 1940) o $8 \mathrm{~mm}$. Dac dactylus in rostral view; PE1-4 pereiopods 1-4 caudal view, detail of carpus 1 in rostral view; Sc1 ornamental sensory spine of carpus 1; Sc4 sensory spine of carpus 4; Sm4 sensory spine of merus 4; Sp1 sensory spine of propus 1 . 


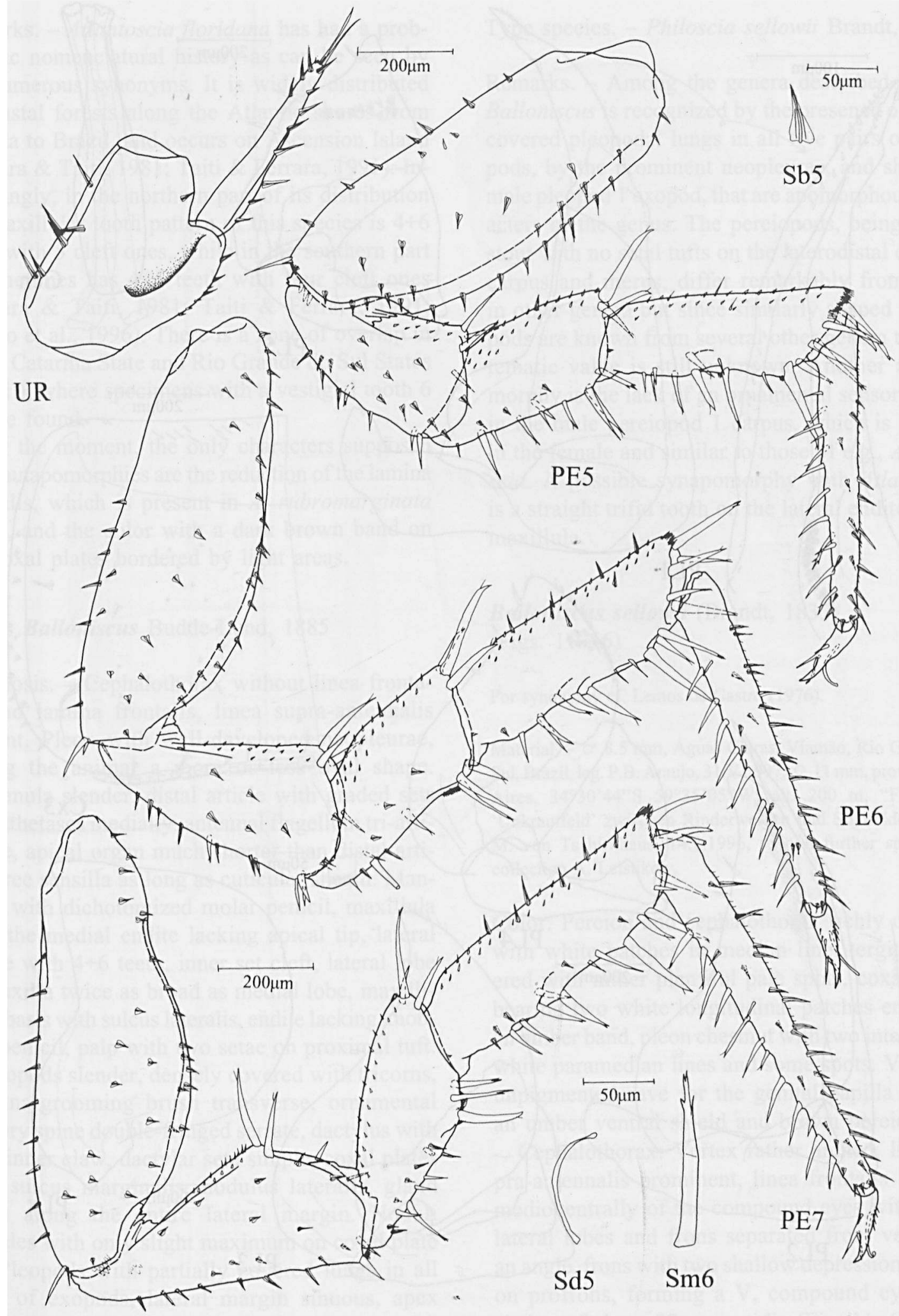

Fig. 9. Atlantoscia floridana (Van Name, 1940) o $8 \mathrm{~mm}$. PE5-7 pereiopods 5-7 in caudal view; Sb5 tricorn-like seta of basis 5; Sd5 dactylar seta of dactylus 5 ; Sm6 sensory spine of merus 6; UR uropod. 


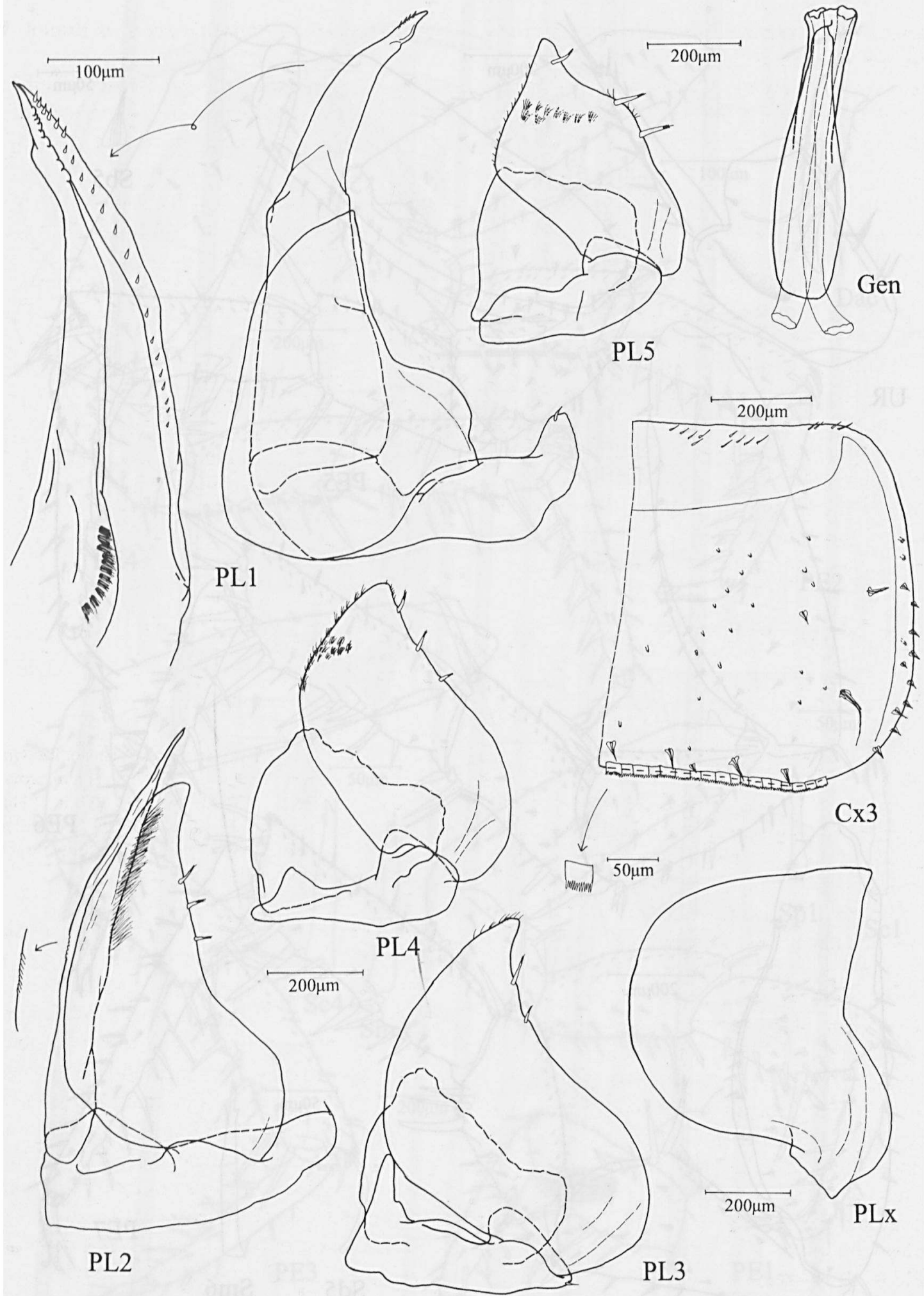

Fig. 10. Atlantoscia floridana (Van Name, 1940) $\sigma \circ 8 \mathrm{~mm}$. Cx3 coxal plate III; Gen genital papilla; PL1-5 pleopods 1-5 with details of endopods 1 (rostrally) and 2 (caudally); Plx pleopod 1 exopod. 
Remarks. - Atlantoscia floridana has had a problematic nomenclatural history as can be seen by the numerous synonyms, It is widely distributed in coastal forests along the Atlantic shores from Florida to Brazil, and occurs on Ascension Island (Ferrara \& Taiti, 1981; Taiti \& Ferrara, 1991). Interestingly, in the northern part of its distribution the maxillular tooth pattern of this species is $4+6$ teeth with 5 cleft ones, while in the southern part it sometimes has $4+5$ teeth with four cleft ones (Ferrara \& Taiti, 1981; Taiti \& Ferrara, 1991; Araujo et al., 1996). There is a zone of overlap in Santa Catarina State and Rio Grande do Sul States (Brazil), where specimens with a vestigial tooth 6 can be found.

For the moment, the only characters supposed to be autapomorphies are the reduction of the lamina frontalis, which is present in A. rubromarginata n. sp., and the color with a dark brown band on the coxal plates bordered by light areas.

\section{Genus Balloniscus Budde-Lund, 1885}

Diagnosis. - Cephalothorax without linea frontalis and lamina frontalis, linea supra-antennalis present. Pleon with well-developed neopleurae, giving the animal a more or less oval shape. Antennula slender, distal article with graded sets of aesthetascs medially, antennal flagellum tri-articulate, apical organ much shorter than distal article, free sensilla as long as cuticular sheath. Mandible with dichotomized molar penicil, maxillula with the medial endite lacking apical tip, lateral endite with $4+6$ teeth, inner set cleft, lateral lobe of maxilla twice as broad as medial lobe, maxillipede basis with sulcus lateralis, endite lacking knoblike penicil, palp with two setae on proximal tuft. Pereiopods slender, densely covered with tricorns, antenna-grooming brush transverse, ornamental sensory spine double-fringed serrate, dactylus with long inner claw, dactylar seta simple, coxal plates with sulcus marginalis, nodulus lateralis, gland pores along the entire lateral margin. Noduli laterales with only slight maximum on coxal plate IV. Pleopods with partially covered lungs in all pairs of exopods, lateral margin sinuous, apex pointed. Male pleopod 1 exopod circular, with sensory spines along entire distal margin. Uropod with endopod inserting proximally of exopod.
Type species. - Philoscia sellowii Brandt, 1833.

Remarks. - Among the genera described herein, Balloniscus is recognized by the presence of semicovered pleopodal lungs in all five pairs of pleopods, by the prominent neopleurae, and shape of male pleopod 1 exopod, that are apomorphous characters of the genus. The pereiopods, being rather stout with no setal tufts on the laterodistal edge of carpus and merus, differ remarkably from those in other genera but since similarly shaped pereiopods are known from several other genera the systematic value is still unknown. Another autapomorphy is the lack of an ornamental sensory spine in the male pereiopod 1 carpus, which is present in the female and similar to those of e.g., Atlantoscia. A possible synapomorphy with Atlantoscia is a straight trifid tooth on the lateral endite of the maxillula.

\section{Balloniscus sellowii (Brandt, 1833)}

(Figs. 11-16)

For synonymy cf. Lemos de Castro (1976).

Material. - o 8.5 mm, Aguas Claras, Viamão, Rio Grande do Sul, Brazil, leg. P.B. Araujo, 31.V.1997; 911 mm, prov. Buenos Aires, $34^{\circ} 30^{\prime} 44^{\prime \prime} \mathrm{S} 59^{\circ} 35^{\prime} 05^{\prime \prime} \mathrm{W}$, alt. $200 \mathrm{~m}$, "Flachland, "Unkrautfeld" zwischen Rinderweiden und Sojafeldern", leg. M. von Tschirnhaus, 14.2.1996, several further specimens, collection A. Leistikow.

Color: Pereion and cephalothorax richly chestnut with white patches in median line, tergites covered-with rather plentiful pale spots, coxal plates bearing two white longitudinal patches enclosing an umber band, pleon chestnut with two interrupted, white paramedian lines and some spots. Ventrally unpigmented save for the genital papilla bearing an umber ventral shield and brown pereiopods.

Cephalothorax: Vertex rather arched, linea supra-antennalis prominent, linea frontalis lacking, medioventrally of the compound eyes with slight lateral lobes and frons separated from vertex by an angle, frons with two shallow depressions joined on profrons, forming a $\mathrm{V}$, compound eyes consisting of about 22 ommatidia (Fig. 11, Ctf).

Pereion: Tegument rather smooth with some small granula on pereionites, coxal plates smooth 


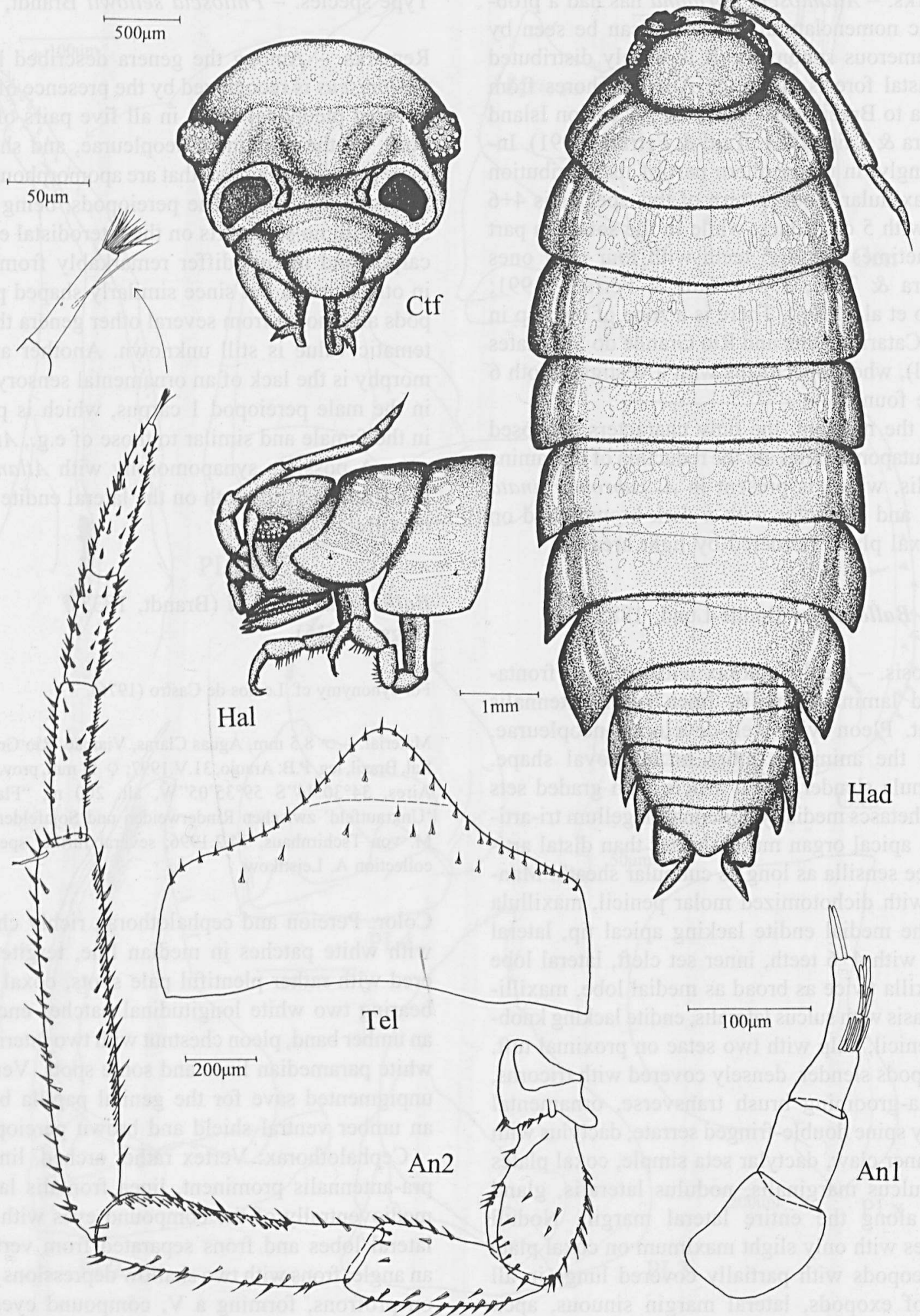

Fig. 11. Balloniscus sellowii (Brandt, 1833) o $8.5 \mathrm{~mm}$. An1 antennula; An2 antenna; Ctf cephalothorax in frontal view; Had habitus in dorsal view; Hal habitus in lateral view; Tel pleotelson. 
with tricorn-like setae, sulcus marginalis bordering elongate zone of gland pores, noduli laterales present on each coxal plate, d/c-coordinates with maximum on coxal plate IV. In ovigerous females coxal plates II to IV separated from pereionite by conspicuous suture (Fig. 16, Cx4).

Pleon: Only slightly retracted from pereion, neopleurae of pleon segments 3 to 5 prominent, somewhat falciform, pleotelson with concave lateral margins, bordered by tricorn-like setae, and some tricorn-like setae on dorsal surface.

Antennula: Articles rather slender, distal one almost as long as proximal two together, bearing apical tuft of aesthetascs and three transverse rows of aesthetascs medially (Fig. 11, An1).

Antenna: Flagellum tri-articulate, all articles subequal in length, distal joint slightly longer, aesthetascs on article 2 and 3, apical organ one fourth of the length of distal article, free sensilla as long as others, peduncle comparatively short, length ratio of article 1 to 5 is $1: 2: 2: 3: 4$, all densely covered with tricorn-like setae (Fig. 11, An2).

Mandible: Pars intermedia with coniform setae and two on left or one penicil on right mandible, molar penicil consisting of 7 to 8 branches, all individualized, additional plumose seta distally of molar penicil (Fig. 12, Mdl/r).

Maxillula: Medial endite apically with two slender penicils, laterodistal margin bearing hair-like setae, no lateral point, lateral endite in the examined specimen with $4+6$ ( 1 vestigial) teeth, with inner set cleft, one trifid, lateral fringe of comparatively few, stout trichiform setae (Fig. 12, Mx1).

Maxilla: Medial lobe half the width of lateral, apically cuspidate, subapically with trichiform setae, lateral lobe with pectinate scales caudally (Fig. 12, $\mathrm{Mx2).}$

Maxillipede: basis with sulcus lateralis, medially of it cuticula scaly, palp with very inconspicuous articulation between distal and medial article, setal tuft of medial article reduced, bearing four setae, proximally of it a pair of one long and one short seta; setae of proximal article long, almost subequally shaped, epipod medially with some scales and pectinate scales (Fig. 12, Mxp).

Pereiopods: Long but fairly stout appendages bearing many tricorn-like setae, carpus 1 with long transverse antenna-grooming brush, deeply furrowed, antagonistic device of propus consisting of a single row of stout setae, dactylus with long inner claw and simple dactylar seta, ornamental sensory spine of carpus 1 with serrate double fringe at its apex, rostrodistal margin of ischium 4 crenulate (Fig. 13, Dac, PE 1-4; Fig. 14, PE 5-7). Sexual differentiation: Male pereiopods 1 to 4 with medial margin of carpus and merus with three to four rows of multi-tipped sensory spines (Fig. 13, Sm1), forming a dense setal comb with loss of characteristic ornamental sensory spine of carpus 1 , which is present in pereiopod of female (Fig. 16, Sc1), cover of sensory spines in carpus and merus 5 to 6 also higher in the male; additionally, merus 6 medioproximally swollen. Male ischium 7 proximally narrowed, looking somewhat funnel-shaped by concave medial margin, proximally grooved.

Pleopods: Pleopodal exopods pointed, with lateral margin very sinuous due to respiratory field of lateroproximal part. Respiratory area laterally crenulate with medial area partially covered by edge of lung atrium, lateral margin bearing many sensory spines (Fig. 15, PL 1-5). Sexual differentiation: Male pleopod 1 exopod rounded with whole margin bearing sensory spines, endopod long and slender, acute, bearing row of spines mediocaudally, some very faint pectinate scales proximally of interlocking area with apex of genital cone. Pleopod 2 exopod somewhat more elongate than exopod of pleopod 3, medial margin with setose area, endopod slender, apical third almost flagelliform, broken off in the examined specimens.

Uropod: Protopod laterally grooved, subtriangular shaped, endopod slightly weaker than exopod, inserting more proximally (Fig. 14, UR).

Genital appendage: Ventral shield coniform, mouths of ductus ejaculatorii somewhat surpassing its apex, no setation discernible in light microscope at $400 \times$ magnification (Fig. 15, Gen).

Remarks. - Vandel (1963) established a new family Balloniscidae for the hitherto known species of South American philosciid species with pleopodal lungs. He mentioned that the lungs are not closed in several species, which furthermore lack a linea frontalis - the Balloniscus Budde-Lund, $1885 \mathrm{~s}$. str. - and separated the species with linea fronta- 


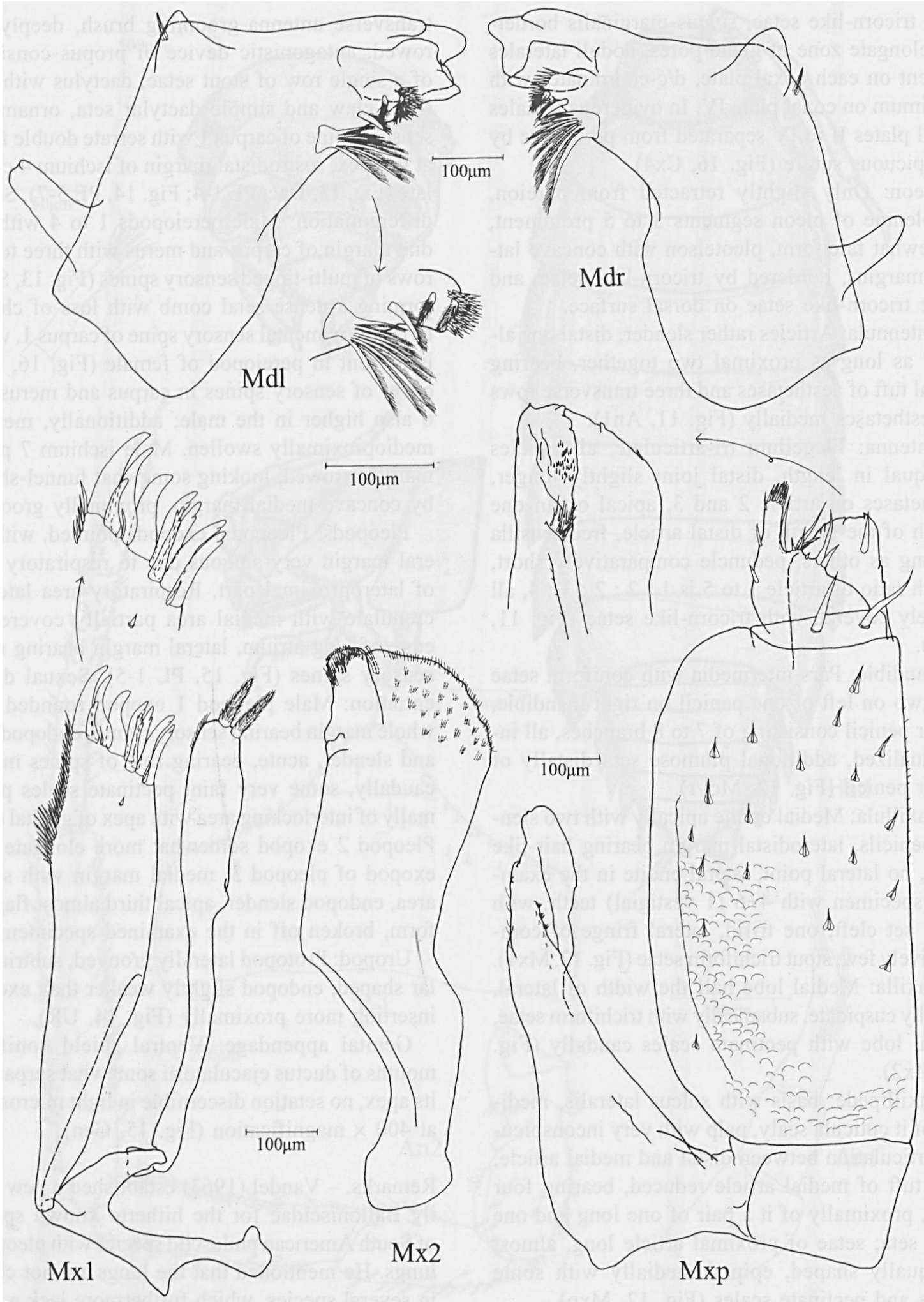

Fig. 12. Balloniscus sellowii (Brandt, 1833) O $^{\circ} 8.5 \mathrm{~mm}$. Mdl/r left and right mandible with detail of pars intermedia of left one; Mxp maxillipede with detail of endite in rostral view; Mxl maxillula with detail of apex of lateral endite; Mx2 maxilla. 


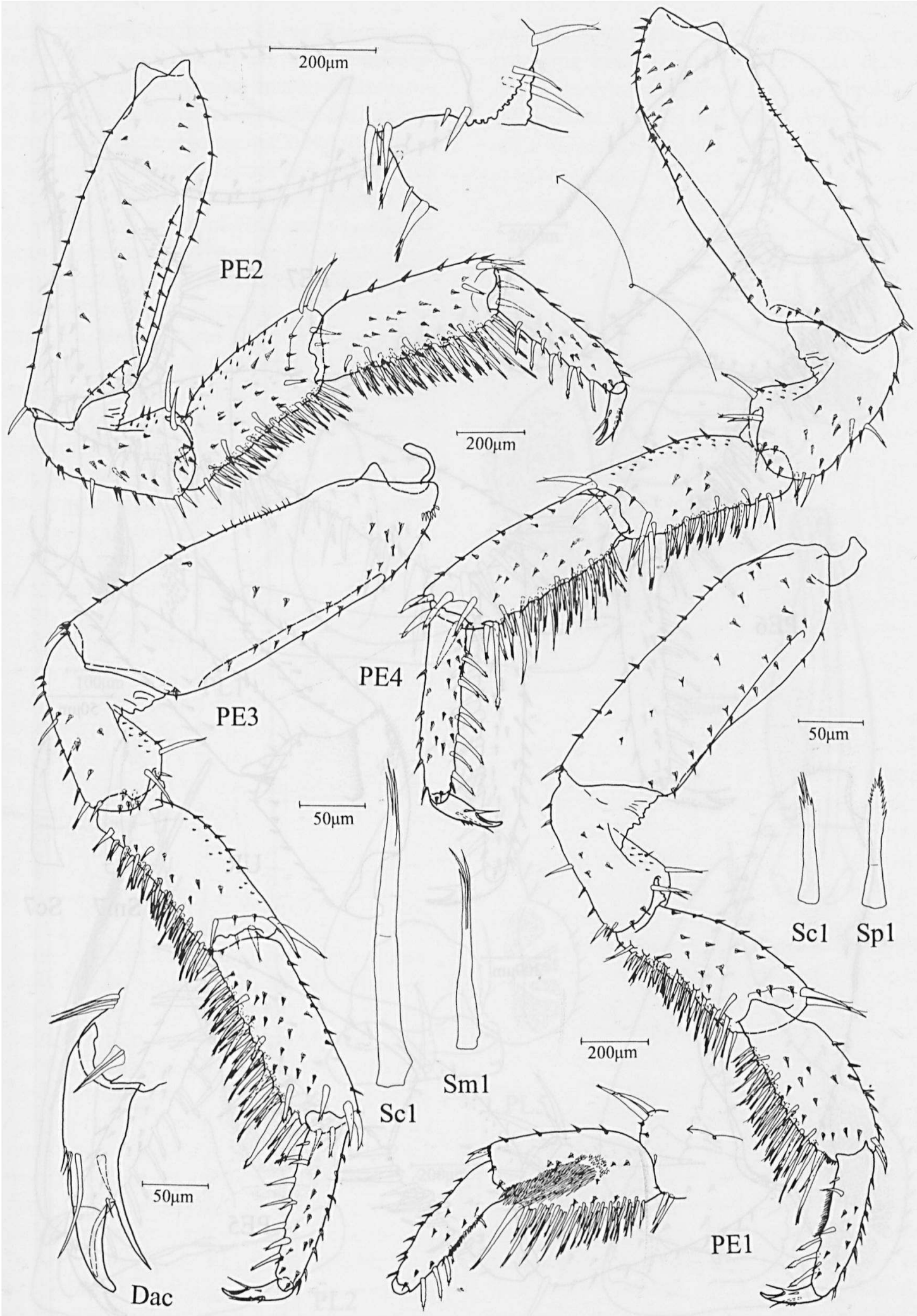

Fig. 13. Balloniscus sellowii (Brandt, 1833) o $8.5 \mathrm{~mm}$. Dac dactylus in rostral view; PE1-4 pereiopods 1-4, caudal view, with detail of propus to carpus 1 and distal margin of ischium 4 in rostral view, respectively; Scl sensory spines of carpus 1; Sm1 sensory spine of meral brush 1; Spl sensory spine of propus 1 . 


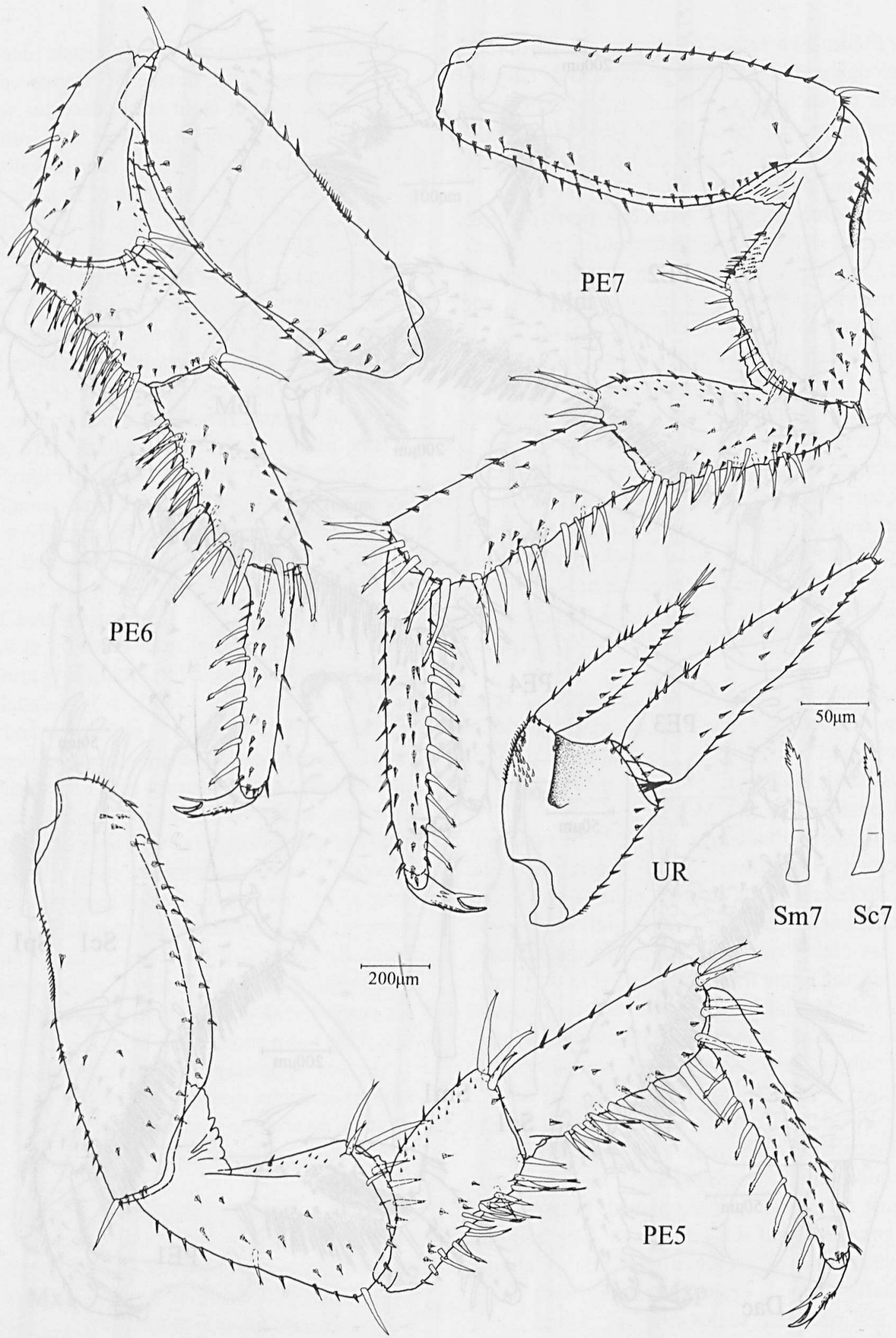

Fig. 14. Balloniscus sellowii (Brandt, 1833) ơ $8.5 \mathrm{~mm}$. PE5-7 pereiopods 5-7; Sc7 sensory spine of carpus 7; $\mathrm{Sm} 7$ sensory spine of merus 7; UR uropod. 


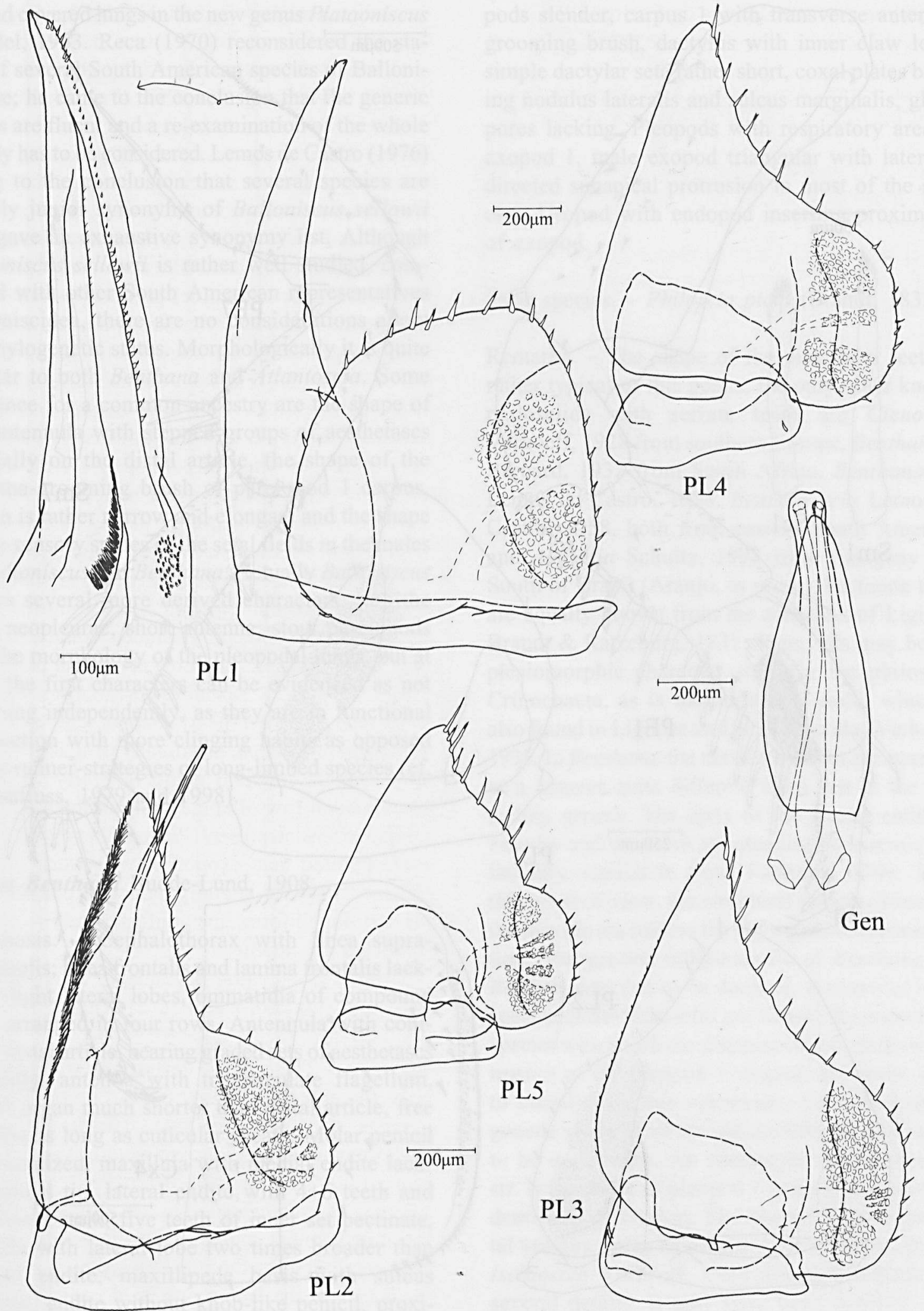

Fig. 15. Balloniscus sellowii (Brandt, 1833) o $8.5 \mathrm{~mm}$. Gen genital papilla; PL1-5 pleopod 1-5. 


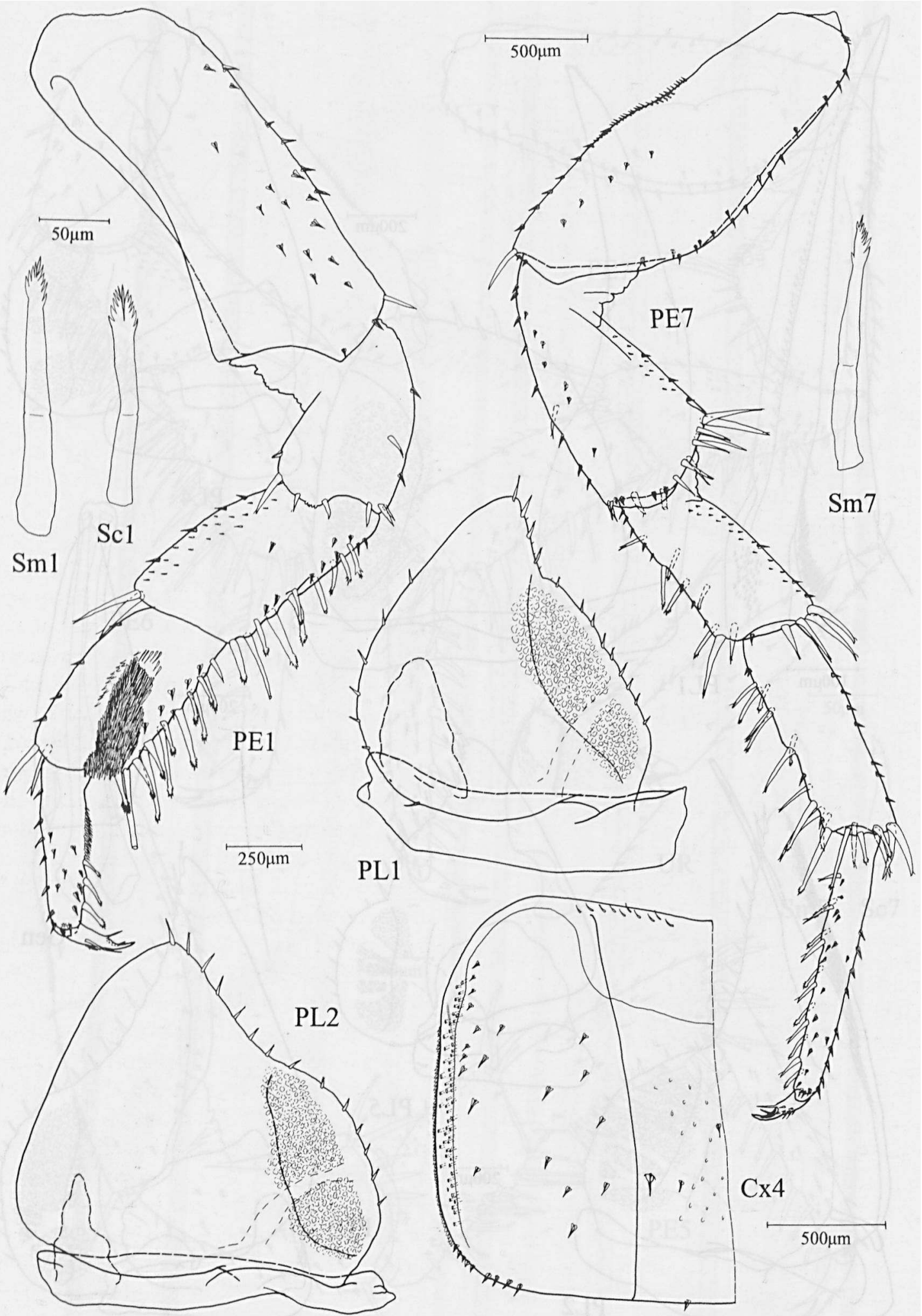

Fig. 16. Balloniscus sellowii (Brandt, 1833) $९ 11 \mathrm{~mm}$ (ovigerous). Cx4 coxal plate 4, note longitudinal sulcus; PE1, PE7 pereiopods 1 (rostrally) and 7 (caudally); PL1-2 pleopods 1-2; Sc1 sensory spine of carpus 1; Sml, 7 sensory spines of merus 1 and 7. 
lis and covered lungs in the new genus Plataoniscus Vandel, 1963. Reca (1970) reconsidered the status of several South American species of Balloniscidae; he came to the conclusion that the generic limits are fluent and a re-examination of the whole family has to be considered. Lemos de Castro (1976) came to the conclusion that several species are merely junior synonyms of Balloniscus sellowii and gave an exhaustive synonymy list. Although Balloniscus sellowii is rather well studied, compared with other South American representatives of Oniscidea, there are no considerations about its phylogenetic status. Morphologically it is quite similar to both Benthana and Atlantoscia. Some evidence for a common ancestry are the shape of the antennula with stepped groups of aesthetascs medially on the distal article, the shape of the antenna-grooming brush of pereiopod 1 carpus, which is rather narrow and elongate and the shape of the sensory spines of the setal fields in the males of Balloniscus and Benthana. Actually Balloniscus shows several more derived characters, i.e., the long neopleurae, short antenna, stout pereiopods and the morphology of the pleopodal lungs, but at least the first characters can be evidenced as not evolving independently, as they are in functional connection with more clinging habits as opposed to the runner-strategies of long-limbed species (cf. Schmalfuss, 1979 and 1998).

\section{Genus Benthana Budde-Lund, 1908}

Diagnosis. - Cephalothorax with linea supraantennalis; linea frontalis and lamina frontalis lacking, slight lateral lobes, ommatidia of compound eyes arranged in four rows. Antennula with coniform distal article, bearing graded sets of aesthetascs medially, antenna with tri-articulate flagellum, apical organ much shorter than distal article, free sensilla as long as cuticular sheath. Molar penicil dichotomized, maxillula with medial endite lacking apical tip, lateral endite with $4+6$ teeth and additional stalk, five teeth of inner set pectinate, maxilla with lateral lobe two times broader than medial endite, maxillipede basis with sulcus lateralis, endite without knob-like penicil, proximal setal tuft of palp comprising two setae. Pereio- pods slender, carpus 1 with transverse antennagrooming brush, dactylus with inner claw long, simple dactylar seta rather short, coxal plates bearing nodulus lateralis and sulcus marginalis, gland pores lacking. Pleopods with respiratory area in exopod 1, male exopod triangular with laterally directed subapical protrusion in most of the species. Uropod with endopod inserting proximally of exopod.

Type species. - Philoscia picta (Brandt, 1833)

Remarks. - The shape of the maxillular teeth is rather typical of this genus; the only other known philosciids with serrate teeth are Ctenoscia Verhoeff, 1928 from southern Europe, Benthanops Barnard, 1932 from South Africa, Benthanoides Lemos de Castro, 1958, Benthanoscia Lemos de Castro, 1958, both from eastern South America, and Alboscia Schultz, 1995 from Paraguay and South of Brazil (Araujo, in press). Pectinate teeth are equally known from the members of Ligiidae Brandt \& Ratzeburg, 1831. Thus, this may be the plesiomorphic character state for the philosciid Crinochaeta, as is the additional stalk, which is also found in Lígíidae and Scleropactidae Verhoeff, 1938. In Benthana, the maxillular teeth are arranged in a manner quite different from that in the preceding genera. The apex of the lateral endite is broader and the teeth are standing in a semicircle laterally, similar to Ligia Fabricius, 1798. From this point of view, the structural features found on the maxilla are useless for phylogenetic reconstruction. The generic independence of Benthana and Benthanoides has to be doubted; it seems as if the species of Benthanoides are simply the more basal species which lack the characteristic dentiform protrusion of the pleopod 1 exopod. However, prior to establishing this synonymy, a detailed phylogenetic study of all the species hitherto known has to be undertaken. An apomorphy of Benthana $\mathrm{s}$. str. is the shape of pleopod 1 exopod with a lateral dentiform protrusion. The shape of the ornamental sensory spine of carpus 1 is similar to that of Ischioscia Verhoeff, 1928 although differing in several details. It may have been evolved independently. 
Benthana convexa Lemos de Castro, 1958 (Figs. 17-22)

Material: ơ 9 mm, Alto de Mosela, Petrópolis, Río de Janeiro, Brazil, leg. Dalcy, 1.36, MNRJ 8194; several

Color: All specimens had faded out to a yellowish buff; muscle insertions on cephalothorax slightly darker.

Cephalothorax: Like the preceding species with small lateral lobes and linea supra-antennalis, linea frontalis lacking, vertex arched, compound eyes consisting of about 20 ommatidia (Fig. 17, Ctf).

Pereion: Slightly convex in cross section, tegument rather smooth, coxal plates with sulcus marginalis and noduli laterales, gland pores lacking, slight maximum of $\mathrm{d} / \mathrm{c}$-coordinates of noduli laterales on coxal plate IV (Fig. 22, Cx4; Fig. 17, Cxp).

Pleon: Conspicuously retracted from pereion with small neopleurae on pleonsegments 3 to 5 , pleotelson with only slightly concave lateral margins, caudally not surpassed by protopods of uropods.

Antennula: Tri-articulate with coniform distal article bearing two pairs of aesthetascs medially and one apically (Fig. 17, An1).

Antenna: Fairly slender with tri-articulate flagellum, flagellar articles subequal in length, proximal one the longest, apical organ short, one third of the length of distal article, with free sensilla as long as cuticular sheath (Fig. 17, An2).

Mandible: Pars intermedia with dense cushion of coniform setae, two penicils and basally some longer setae on left mandible, right side with fewer setae and single penicil, additional plumose seta proximally, molar penicil consisting of about 9 individualized branches (Fig. 18, Mdl/r).

Maxillula: Medial endite pointed, with two slender penicils apically, lateral endite apically bearing $4+6$ teeth, five of inner set pectinate, lateral fringe composed of rather stout setae compared with other genera (Fig. 18, Mx1).

Maxilla: Medial lobe half as broad as lateral lobe, covered with trichiform setae, apically cuspidate, lateral endite almost lacking setation, some very fine setae laterally (Fìg. 18, Mx2).

Maxillipede: Basis with sulcus marginalis, proximally cuticula slightly scaled, endite with strong tooth and two laterodistal hooks, rostrally lacking knob-like penicil, longitudinal ridge bearing some setae, laterally very fine setation, palp with proximal setal tuft composed of long and short seta, medial tuft bearing four setae (Fig. 18, Mxp).

Pereiopods: All articles bearing several tricorns, carpus 1 with transverse antenna grooming brush, covering a groove which almost reaches lateral margin of carpus, proximally of it some cuticular scales and crest of trichiform setae; ornamental sensory spine with hand-like apex. Ischium 7 with 5 prominent sensory spines grouped laterally, dactylus with simple dactylar seta, inner claw prominent, longer than inter-ungual seta (Fig. 19, Dac, PE 1-4; Fig. 20, PE 5-7). Sexual differentiation: Male pereiopods 1 to 4 with carpus and merus medially bearing 3 to 4 rows of deeply cleft sensory spines, ischium of pereiopod 7 with a more concave medial margin in the male, male merus 7 strongly concave medially, giving it an arcuate appearance, mediodistally with cuticular scales.

Pleopods: Male pleopodal exopods laterally with 5 sensory spines in pleopod 5 to 8 spines in pleopod 3, endopods laterally sinuous, convex in pleopod 5, small respiratory area at least in pleopod 1 (Fíg. 21, PL 1-5). Sexual differentiation: Pleopod 1 exopod inverted heart-shaped, laterally with subapical protrusion, proximally of it about 3 sensory spines, endopod acute, laterally incurved, caudomedial row of spines only in medial part of normal extension present. Pleopod 2 exopod slightly more pointed than exopod 3, with same number of sensory spines laterally, endopod pointed, distal part flagelliform, apex unfortunately broken in dissected specimen.

Uropod and genital appendage: As in generic diagnosis (Fig. 20, UR; Fig. 21, Gen).

Remarks. - The original description was based on only three females from Cantareira, São Paulo (Lemos de Castro, 1958a). The above given description completes the characterization with the male traits. The species differs from its closest relative, $B$. schubarti Lemos de Castro, 1958 by the much longer antennae and the shape of the sublateral tooth of the maxillula, which is of half the length of the lateral one in $B$. convexa Lemos de Castro, 1958 and much smaller in $B$. schubarti (Lemos de Castro, 1958a). These two species seem 


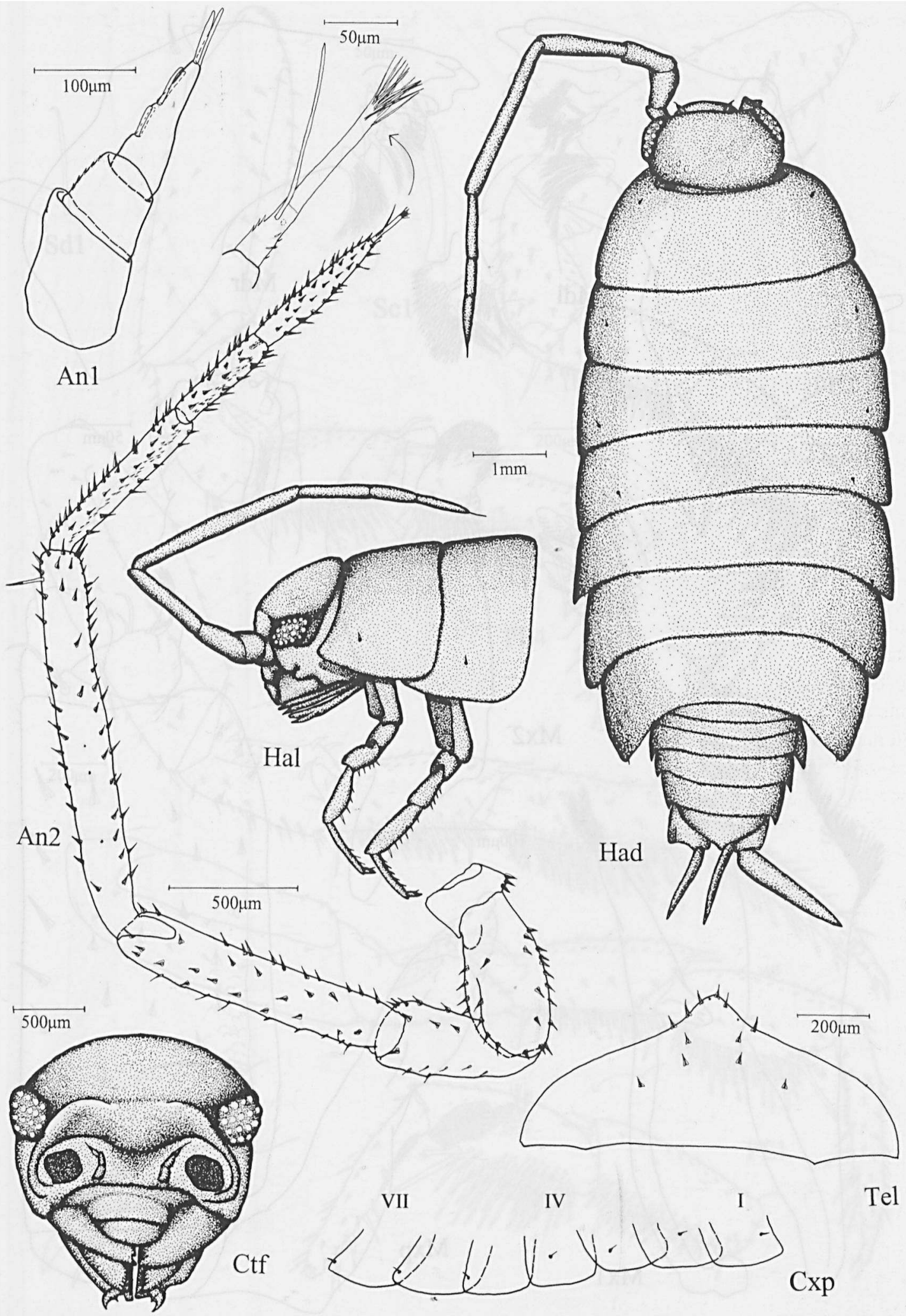

Fig. 17. Benthana convexa Lemos de Castro, 1958 o* $9 \mathrm{~mm}$. Anl antennula; An2 antenna; Ctf cephalothorax in frontal view; Cxp position of noduli laterales; Had habitus in dorsal view; Hal habitus in lateral view; Tel pleotelson. 


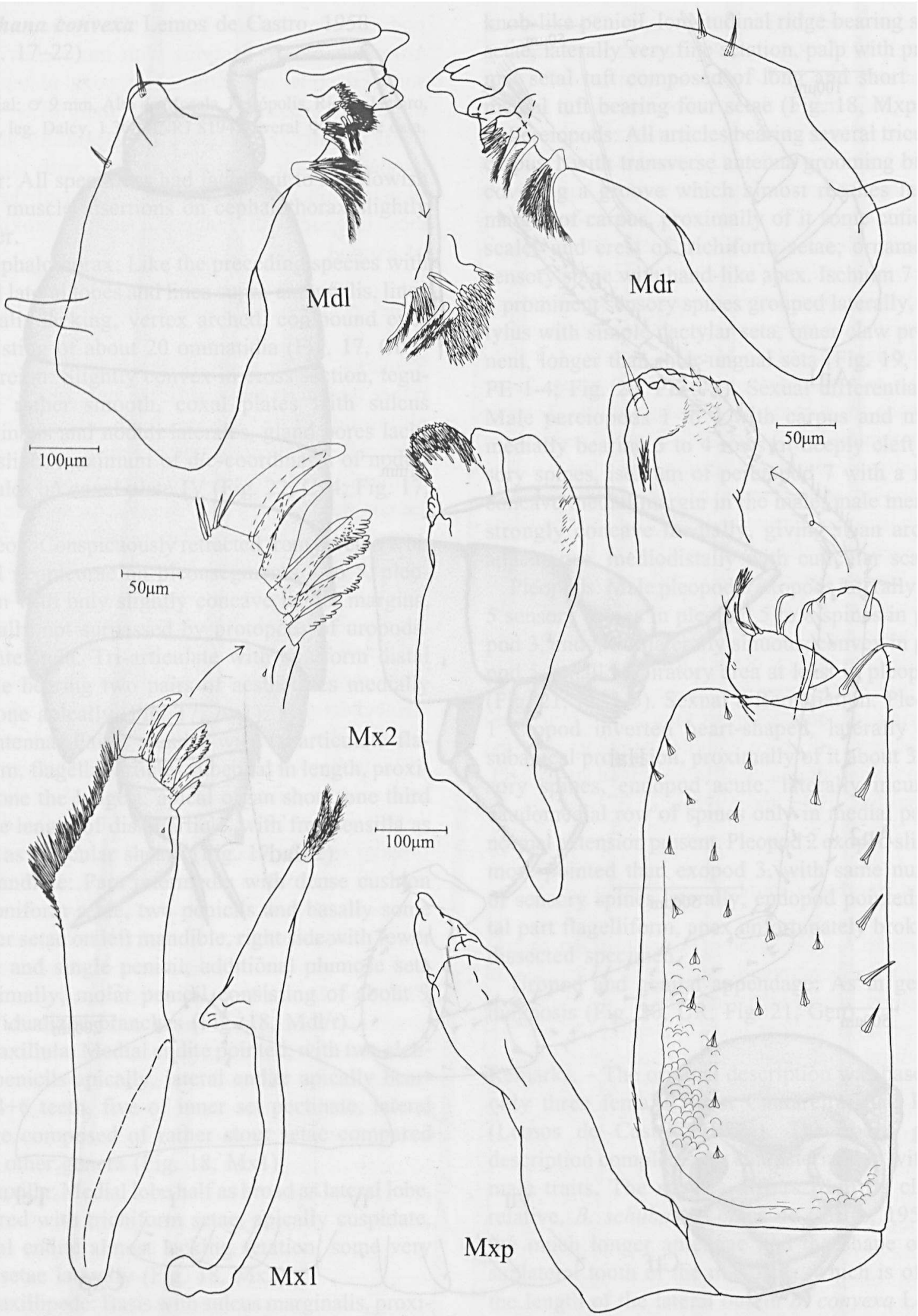

Fig. 18. Benthana convexa Lemos de Castro, 1958 o $9 \mathrm{~mm}$. Mdl/r left and right mandible with detail of pars intermedia of left one; Mxp maxillipede with detail of endite in rostral view; Mx1 maxillula with detail of apex of lateral endite; Mx2 maxilla. 


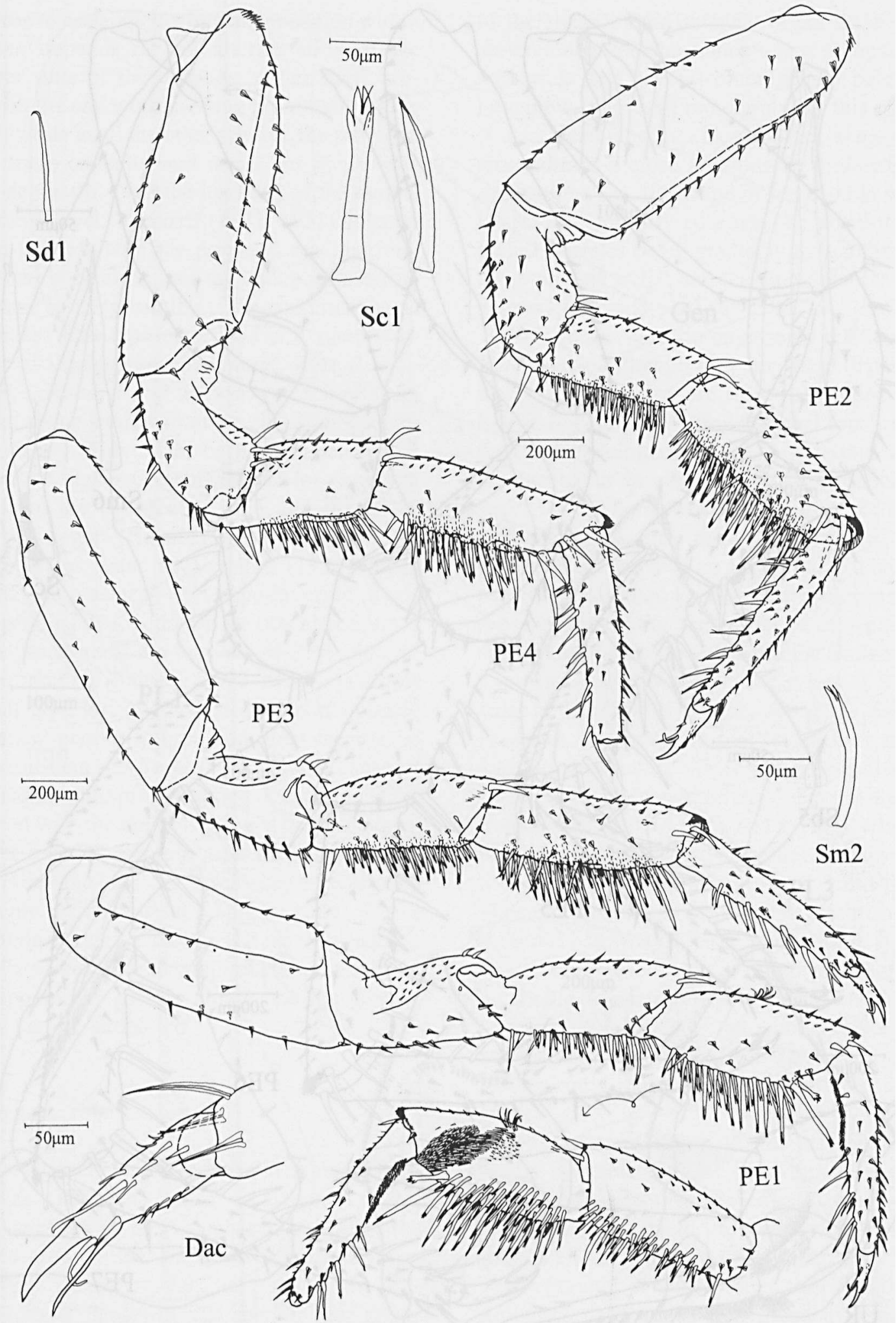

Fig. 19. Benthana convexa Lemos de Castro, 1958 o $9 \mathrm{~mm}$. Dac dactylus in rostral view; PE1-4 pereiopods 1-4 caudal view, detail of carpus 1 in rostral view; Scl ornamental sensory spine and sensory spine of brush of carpus 1; Sdl dactylar seta of dactylus 1; Sm2 sensory spine of meral brush 2. 


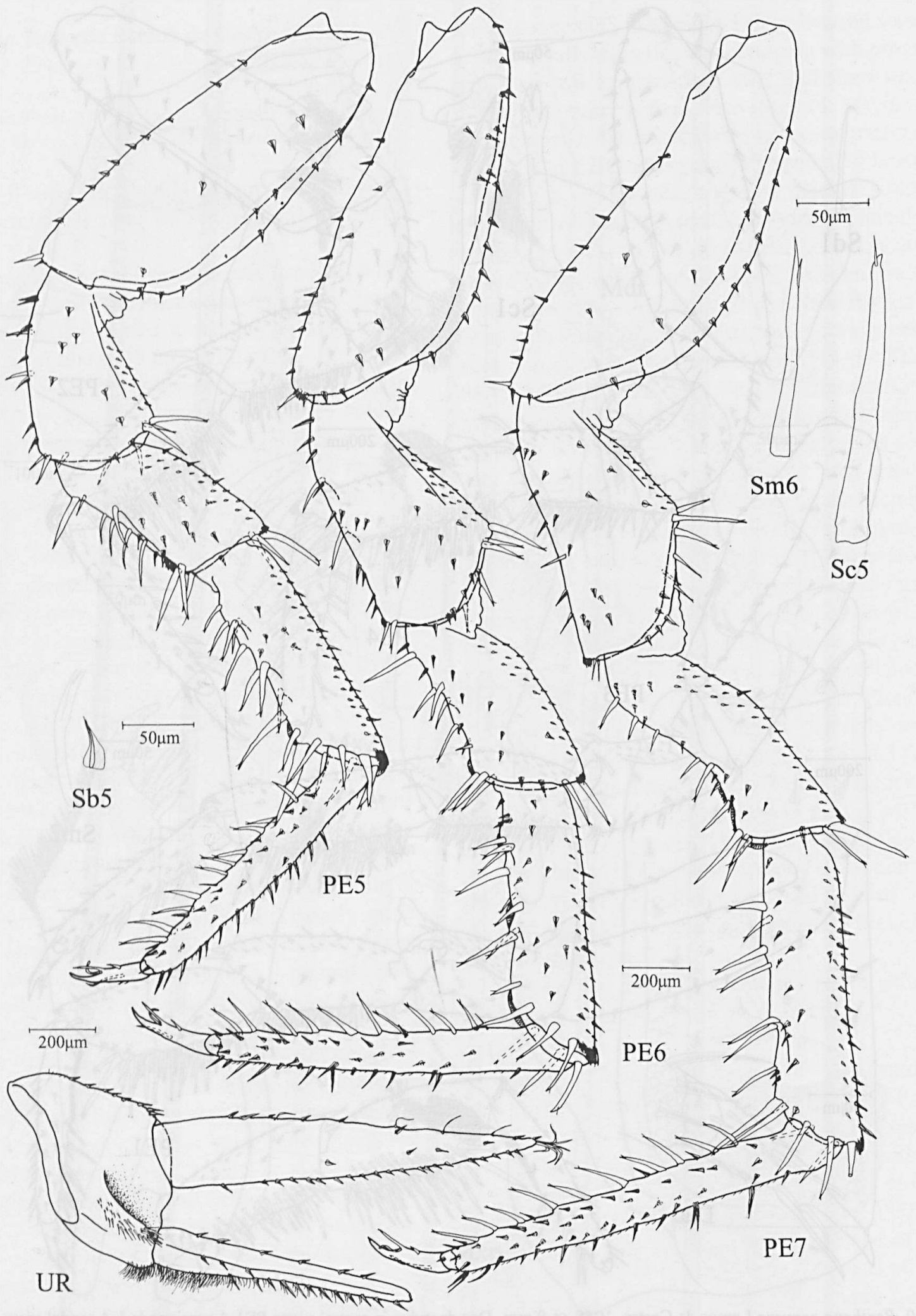

Fig. 20. Benthana convexa Lemos de Castro, 1958 ơ $9 \mathrm{~mm}$. PE5-7 pereiopods. 5-7; Sb5 tricom-like seta of basis 5; Sc5 sensory spine of carpus 5; Sm6 sensory spine of merus 6; UR uropod. 


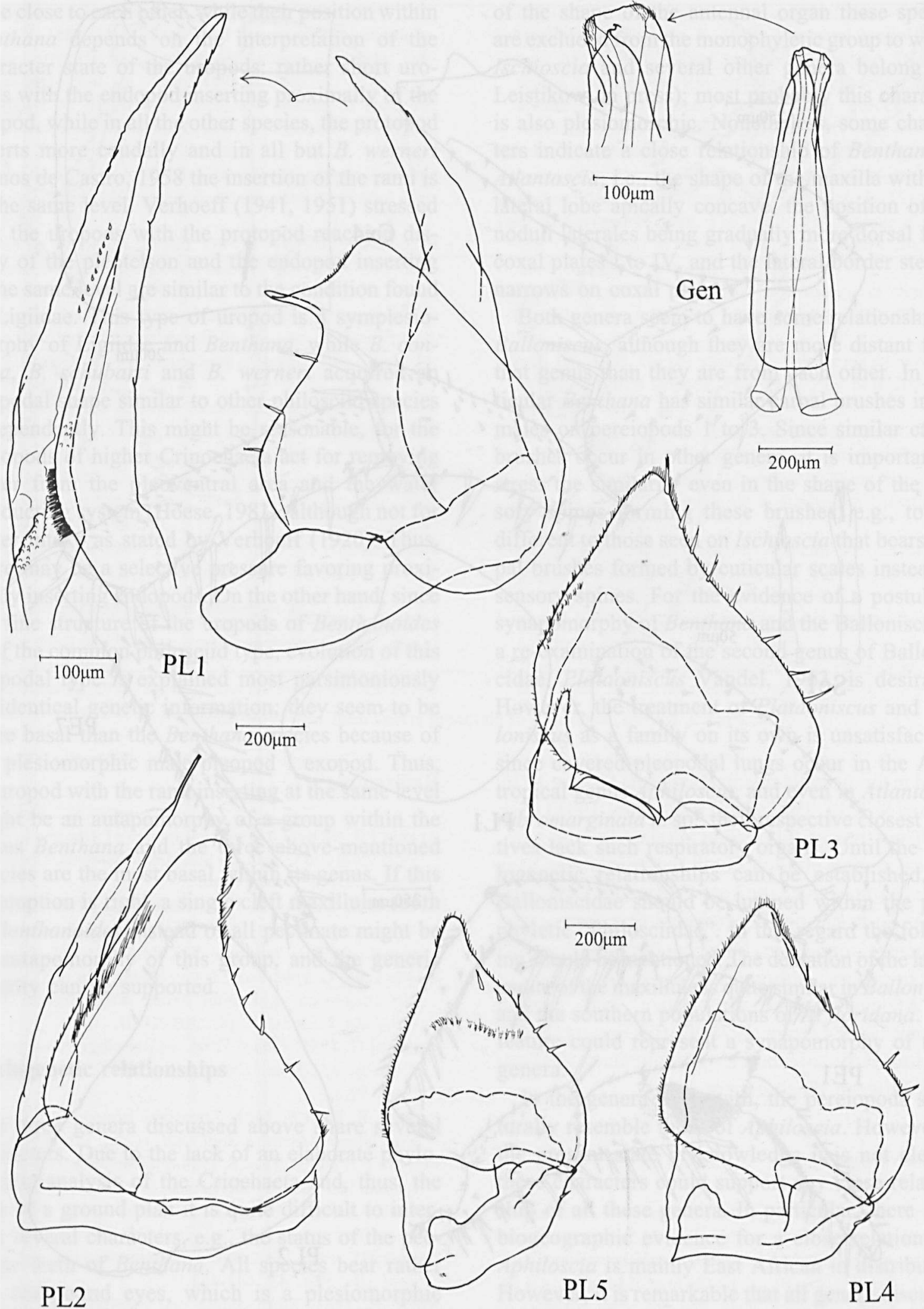

Fig. 21. Benthana convexa Lemos de Castro, 1958 o $9 \mathrm{~mm}$. Gen genital papilla; PL1-5 pleopod 1-5. 


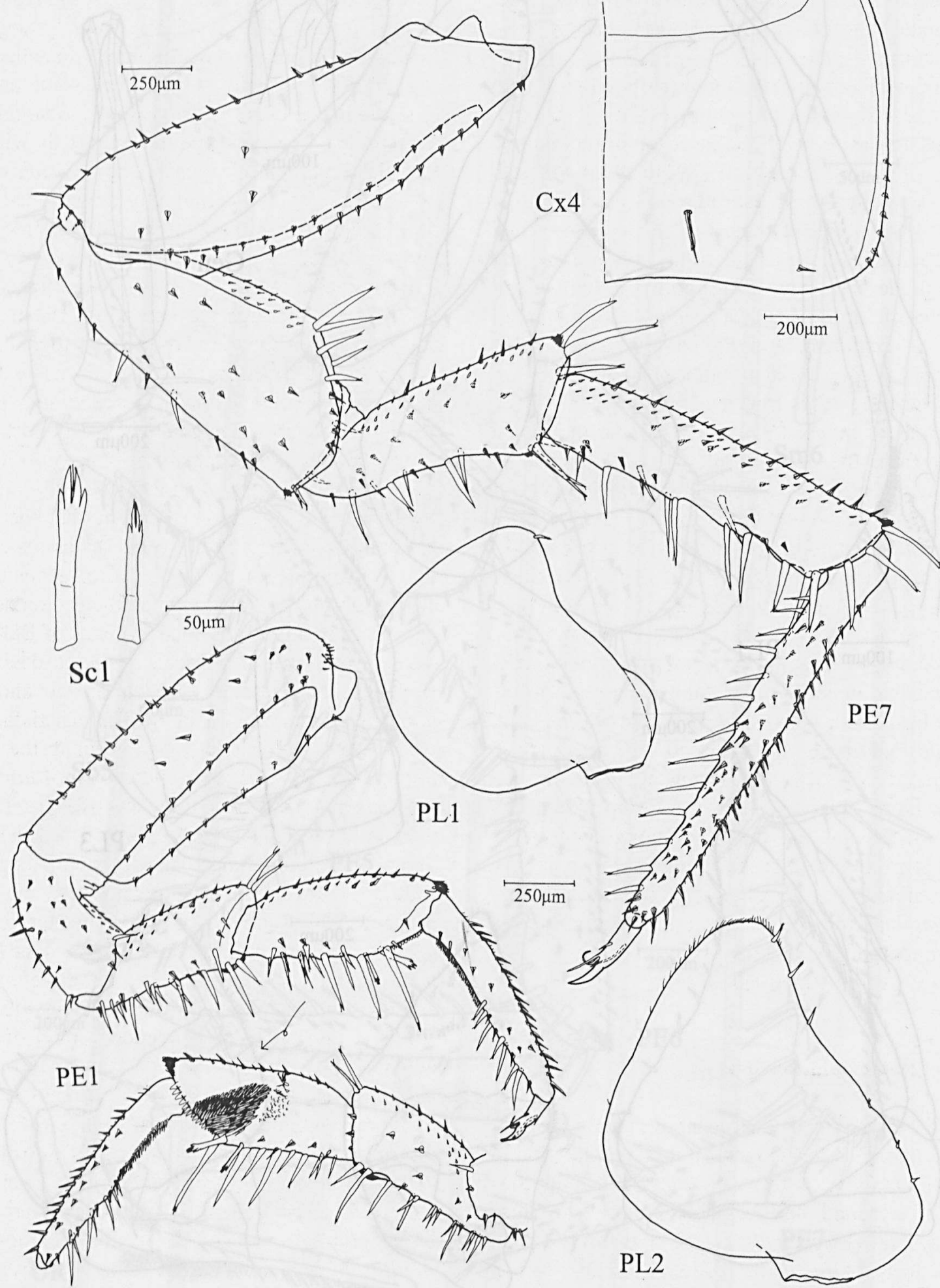

Fig. 22. Benthana convexa Lemos de Castro, 1958 \& $11 \mathrm{~mm}$. Cx4 coxal plate 4; PE1, PE7 pereiopods 1 and 7 (caudally), with detail of pereiopod 1 rostrally; PL1-2 pleopod 1-2 exopods; Scl sensory spines of carpus 1. 
to be close to each other, while their position within Benthana depends on the interpretation of the character state of the uropods: rather short uropods with the endopod inserting proximally of the exopod, while in all the other species, the protopod inserts more caudally and in all but $B$. werneri Lemos de Castro, 1958 the insertion of the rami is at the same level. Verhoeff $(1941,1951)$ stressed that the uropods with the protopod reaching distally of the pleotelson and the endopod inserting at the same level are similar to the condition found in Ligiidae. This type of uropod is a symplesiomorphy of Ligiidae and Benthana, while $B$. convexa, $B$. schubarti and $B$. werneri acquired an uropodal shape similar to other philosciid species independently. This might be reasonable, for the endopods of higher Crinochaeta act for removing water from the pleoventral area and the water conducting system (Hoese, 1981), although not for water intake as stated by Verhoeff (1920). Thus, there may be a selective pressure favoring proximally inserting endopods. On the other hand, since the fine structure of the uropods of Benthanoides is of the common philoscilid type, evolution of this uropodal type is explained most parsimoniously by identical genetic information; they seem to be more basal than the Benthana species because of the plesiomorphic male pleopod 1 exopod. Thus, an uropod with the rami inserting at the same level might be an autapomorphy of a group within the genus Benthana and the three above-mentioned species are the most basal within its genus. If this assumption is right, a single cleft maxillular tooth in Benthanoides instead of all pectinate might be an autapomorphy of this group, and the generic identity can be supported.

\section{Phylogenetic relationships}

The three genera discussed above share several characters. Due to the lack of an elaborate phylogenetic analysis of the Criochaeta and, thus, the lack of a ground plan it is quite difficult to interpret several characters, e.g., the status of the pectinate teeth of Benthana. All species bear rather. big compound eyes, which is a plesiomorphic character compared to other Oniscidea. By virtue of the shape of the antennal organ these species are excluded from the monophyletic group to which Ischioscia and several other genera belong (cf. Leistikow, in press); most probably this character is also plesiomorphic. Nonetheless, some characters indicate a close relationship of Benthana to Atlantoscia, i.e., the shape of the maxilla with the lateral lobe apically concave, the position of the noduli laterales being gradually more dorsal from coxal plates I to IV, and the lateral border steeply narrows on coxal plate $\mathrm{V}$.

Both genera seem to have some relationship to Balloniscus, although they are more distant from that genus than they are from each other. In particular Benthana has similar carpal brushes in the males on pereiopods 1 to 3 . Since similar carpal brushes occur in other genera, it is important to stress the similarity even in the shape of the sensory spines forming these brushes, e.g., totally different to those seen on Ischioscia that bears carpal brushes formed by cuticular scales instead of sensory spines. For the evidence of a postulated synapomorphy of Benthana and the Balloniscidae, a re-examination of the second genus of Balloniscidae, Plataoniscus Vandel, 1963, is desirable. However, the treatment of Plataoniscus and Balloniscus as a family on its own is unsatisfactory, since covered pleopodal lungs occur in the Afrotropical genus Aphiloscia, and even in Atlantoscia rubromarginata $\mathrm{n} . \mathrm{sp}$; their respective closest relatives lack such respiratory organs. Until the phylogenetic relationships can be established, the Balloniscidae should be lumped within the paraphyletic "Philosciidae". In this regard the following should be mentioned. The dentation of the lateral endite of the maxillula is quite similar in Balloniscus and the southern populations of A.floridana. This feature could represent a synapomorphy of these genera.

In the genera dealt with, the pereiopods structurally resemble those of Aphiloscia. However, at the present state of knowledge it is not clear if these characters could support any close relationship of all these genera. In particular, there is no biogeographic evidence for a close relationship; Aphiloscia is mainly East African in distribution. However, it is remarkable that all genera discussed above are mainly of East Brazilian distribution and 


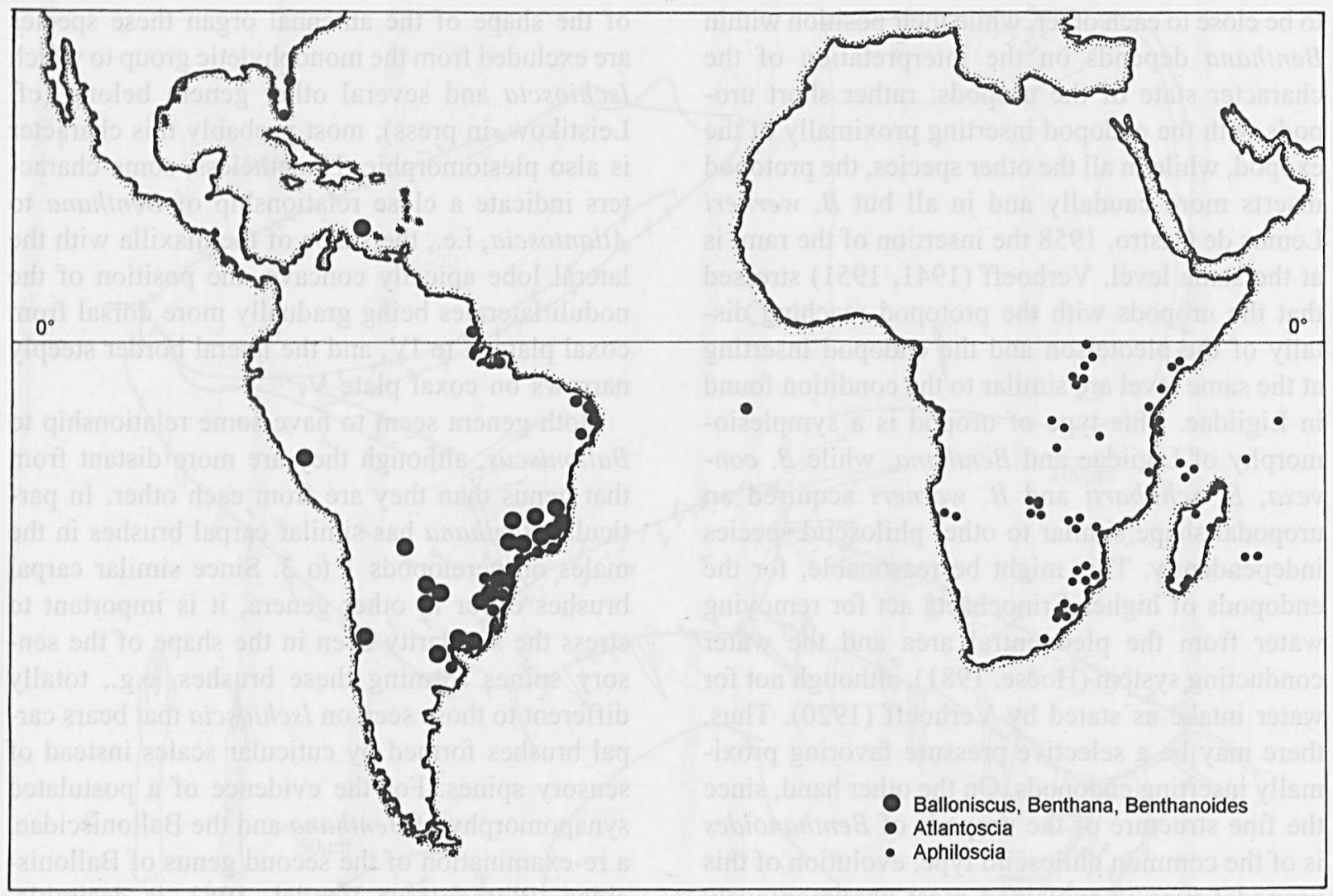

Fig. 23. Known distribution of philosciid genera dealt with in this work.

found in the Atlantic region (Lemos de Castro, 1976; Ferrara \& Taiti, 1981; Taiti \& Ferrara, 1991) (Fig. 23). The fauna of this region is related to the Afrotropical region although both tectonic plates have been separated since the Late Cretaceous (Emiliani, 1995). So it can not be excluded that there exists an ancient connection between the Brazilian and African genera. Although the philosciid genera of the African tropics are rather well studied (Schmalfuss \& Ferrara, 1978; Taiti \& Ferrara, 1980), it is too early to establish phylogenetic relationships between those genera.

\section{Acknowledgements}

The authors wish to express their thanks to Dr. Erminda da Conceição G. Couto, Universidade Federal de Sergipe, Brazil, who donated the material of Atlantoscia rubromarginata n. sp., Dr. P. Young (MNRJ), Brazil, for the loan of material, and Dr. S. Taiti, CNR, Florence, Italy, for providing material of Aphiloscia vilis Budde-Lund, 1908.

\section{References}

Araujo PB. (in press). Two new species of Alboscia Schultz, 1995 from Rio Grande do Sul, Brazil (Isopoda, Oniscidea, Philosciidae). Crustaceana.

Araujo PB, Buckup L, Bond-Buckup G. 1996. Isópodos terrestres (Crustacea, Oniscidea) de Santa Catarina e Rio Grande do Sul. Iheringia, Ser. Zool. 81: 111-138.

Budde-Lund G. 1908. Isopoda von Madagaskar und Ostafrika mit Diagnosen verwandter Arten. Wiss. Ergebn. Reise Ostafrika 2: 263-308, pls. XII-XVIII.

Emiliani C. 1995. Planet Earth - Cosmology, Geology and Evolution of Life and Environment. New York: Cambridge Univ. Press.

Ferrara F, Taiti S. 1981. Terrestrial isopods from Ascension Island. Monitore Zool. Ital. (N.S.) 14: 189-198.

Ferrara F, Paoli P, Taiti S. 1994. Philosciids with pleopodal lungs? The case of the genus Aphiloscia Budde-Lund, 1908 (Crustacea, Isopoda, Oniscidea) with a description of six new species. J. Nat. Hist. 28: 1231-1264.

Gruner HE. 1955. Die Gattung Benthana Budde-Lund, 1908. Zool. Jb., Syst. 83: 441-452.

Hoese B. 1981. Morphologie und Funktion des Wasserleitungssystems der terrestrischen Isopoden (Crustacea, 
Isopoda, Oniscoidea). Zoomorphology 98: 135-167.

Hoese B. 1983. Morphologie und Evolution der Lungen bei den terrestrischen Isopoden (Crustacea, Isopoda, Oniscoidea). Zool, Jb., Anat. 109: 487-501.

Leistikow A. (in press). Three new species of terrestrial isopods from Panama (Crustacea: Isopoda: Oniscidea). Stud. Neotrop. Fauna Environm. 33.

Lemos de Castro A. 1958a. Revisão do gênero Benthana Budde-Lund, 1908 (Isopoda, Oniscídae). Arq. Mus. Nac. 46: 85-118.

Lemos de Castro A. 1958b. On the systematic position of some American species of Philoscia Latreille, 1804, Amer. Mus. Nov. 1908: 1-10.

Lemos de Castro A. 1976. Consideraçôes sobre a sinonímia e a distribuição geogrăfica de Balloniscus sellowil (Brandt, 1833) (Isopoda, Balloniscidae), Revta. Bras. Biol. 36: 392-391.

Lemos de Castro A. 1985. Considerações sobre Atlantoscia alceui Ferrara \& Taiti, 1981 (Isopoda, Oniscoidea, Philosciidae). Revta. Bras. Biol. 45: 417-422.

Moreira C. 1927. Duas espécies novas de crustáceos isópodes terrestres do Brasil, Bolm. Biol. Lab. Parasit. Fac. Med. S. Paulo 10: 194-200.

Name GW. van 1940. A supplement to the American land and freshwater isopod crustacea. Bull. Am. Mus. Nat. Hist. 77: 109-142.

Reca AR 1970. Oniscoídeos argentinos. I. Sobre la posición sistematica de Philoscia argentina Giambiagi, 1939. Physis 29: $423-429$.

Schmalfuss H. 1979. Ligia simoni. A model for the evolution of terrestrial isopods. Stuttg. Beitr. Naturk. Ser. A 317: 1-5.

Sehmalfuss H. 1998. Evolutionary strategies of the anten- nae in terrestrial îsopods. $J$. Crust. Biol. 18: 10-24.

Sehmalfuss H, Ferrara F. 1978. Terrestrial isopods from west Africa. Part 2: Families Tylidae, Ligiidae, Trichoniscidae, Styloniscidae, Rhyscotidae, Halophilosciídae, Philosciidae, Platyarthridae, Trachelipidae, Porcellionidae, Armadillidiidae. Monitore Zool. Ital. 11: 15-97.

Schultz GA, Johnson C. 1984. Terrestrial isopod crustaceans from Florida (Tylidae, Ligiidae, Halophilosciidae, Philosciidae, Rhyscotidae). J. Crust. Biol. 4: 154-171.

Taiti S, Ferrara F. 1980. The family Philosciidae (Crustacea, Oniscoidea) in Africa south of the Sahara. Monitore Zool. Ital. (N.S.)(Suppl.), 12: 53-98.

Taiti S, Ferrara F. 1991. Two new species of terrestrial isopods from Ascension Island. J. Nat. Hist. 25: 901916.

Unwin EE. 1932. On the structure of the respiratory organs of the terrestrial Isopoda. Pap. Proc. Roy. Soc. Tasmania 1931: 37-104.

Vandel A. 1963. Isopodes terrestres receuillis en Amérique du Sud par C.D. Debouteville. In: Debouteville CD, Rapoport EH eds. Biologie de l'Amérique Australe. Paris: Edítions du Centre Nationale de la Recherche Scientifique, 2: $63-100$.

Verhoeff KW. 1920. Über die Atmung der Landasseln, zugleich ein Beitrag zur Kenntnis der Entstehung der Landtiere. Z. Wiss. Zool. 118: 365-447.

Verhoeff KW. 1941. Zur Kenntnis südamerikanischer Oniscoideen. Zool. Anz. 133: 114-126.

Verhoeff KW. 1951. Landisopoden aus Sũdamerika. Further Zool. Res. Swed. Antarkt. Exp. 4: 1-19.

Received: 28 September 1998 